OAK RIDGE

NATIONAL LABORATORY

MANAGED BY UT-BATTELLE

FOR THE DEPARTMENT OF ENERGY

\title{
Initial Business Case Analysis of Two Integrated Heat Pump HVAC Systems for Near-Zero-Energy Homes
}

Van Baxter

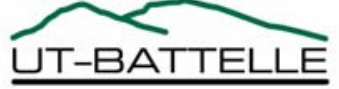




\section{DOCUMENT AVAILABILITY}

Reports produced after January 1, 1996, are generally available free via the U.S. Department of Energy (DOE) Information Bridge:

Web site: http://www.osti.gov/bridge

Reports produced before January 1, 1996, may be purchased by members of the public from the following source:

National Technical Information Service

5285 Port Royal Road

Springfield, VA 22161

Telephone: 703-605-6000 (1-800-553-6847)

TDD: 703-487-4639

Fax: 703-605-6900

E-mail: info@ntis.fedworld.gov

Web site: http://www.ntis.gov/support/ordernowabout.htm

Reports are available to DOE employees, DOE contractors, Energy Technology Data Exchange (ETDE) representatives, and International Nuclear Information System (INIS) representatives from the following source:

Office of Scientific and Technical Information

P.O. Box 62

Oak Ridge, TN 37831

Telephone: 865-576-8401

Fax: 865-576-5728

E-mail: reports@adonis.osti.gov

Web site: http://www.osti.gov/contact.html

This report was prepared as an account of work sponsored by an agency of the United States Government. Neither the United States government nor any agency thereof, nor any of their employees, makes any warranty, express or implied, or assumes any legal liability or responsibility for the accuracy, completeness, or usefulness of any information, apparatus, product, or process disclosed, or represents that its use would not infringe privately owned rights. Reference herein to any specific commercial product, process, or service by trade name, trademark, manufacturer, or otherwise, does not necessarily constitute or imply its endorsement, recommendation, or favoring by the United States Government or any agency thereof. The views and opinions of authors expressed herein do not necessarily state or reflect those of the United States Government or any agency thereof. 
Engineering Science and Technology Division

\title{
Initial Business Case Analysis of Two Integrated Heat Pump HVAC Systems for Near-Zero-Energy Homes (NZEH)
}

\author{
Van Baxter \\ Oak Ridge National Laboratory
}

November 2006

\section{Prepared by}

Oak Ridge National Laboratory

P.O. Box 2008, Oak Ridge, Tennessee 37831-6285, managed by UT-Battelle, LLC

for the

U.S. Department of Energy under contract DE-AC05-00OR22725 



\section{CONTENTS}

LIST OF FIGURES ….................................................................................... iv

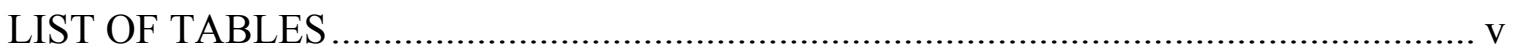

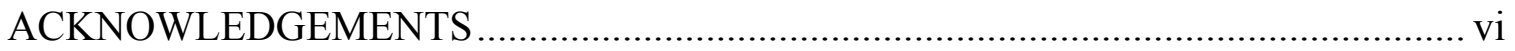

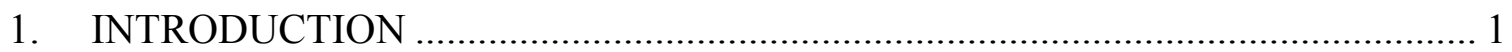

2. ASSESSMENT APPROACH .......................................................................... 2

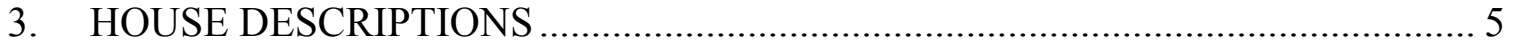

4. DESCRIPTION OF HVAC SYSTEM OPTIONS ............................................... 8

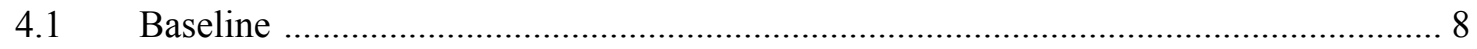

4.2 Centrally Ducted Air-Source Integrated Heat Pump (AS-IHP) .................................. 9

4.3 Centrally Ducted Ground-Source Integrated Heat Pump (GS-IHP) ........................... 10

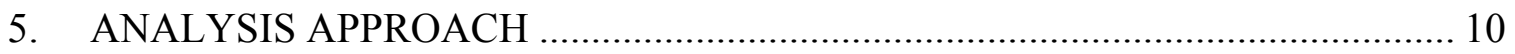

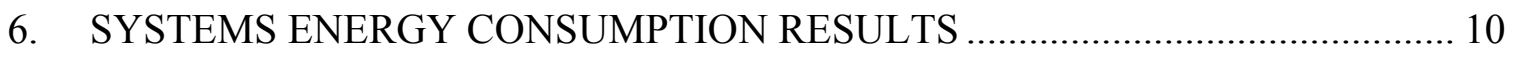

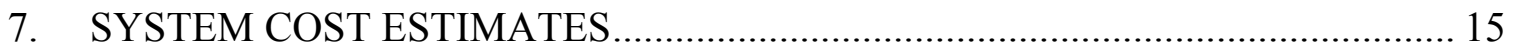

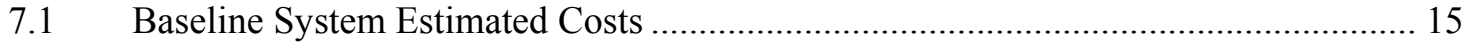

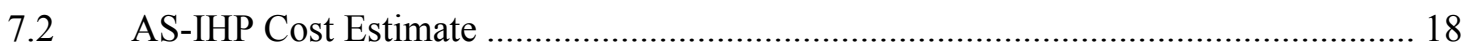

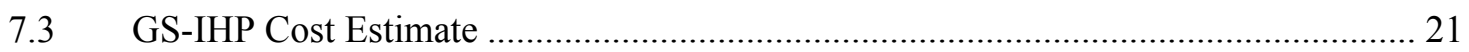

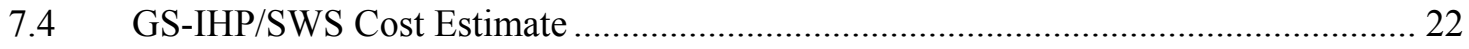

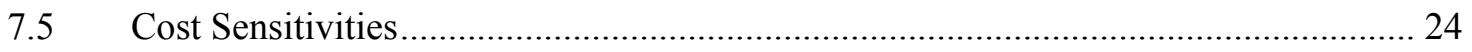

7.6 Approximate IHP Impact on Photovoltaic (PV) System Costs for a ZEH ................. 27

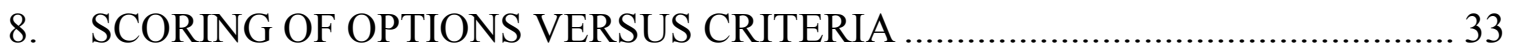

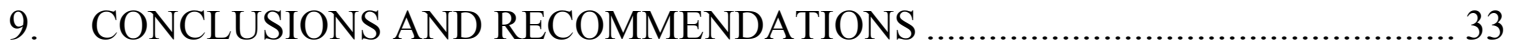

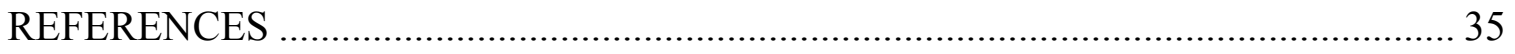

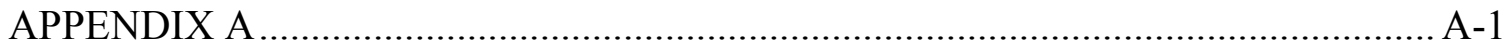




\section{LIST OF FIGURES}

Fig. 1. Net mortgage and utilities cost vs. source energy savings for $1800-\mathrm{ft}^{2}$ house in Atlanta with BA benchmark at $0 \%$ energy savings point and prototype NZE house at $\sim 55 \%$ energy savings point (i.e., take-off point).

Fig. 2. DOE2 vs. TRNSYS heating loads for $1800-\mathrm{ft}^{2}$ NZEH. .....................................

Fig. 3. DOE2 vs. TRNSYS cooling loads for $1800-\mathrm{ft}^{2}$ NZEH. ....................................

Fig. 4. Conceptual diagram of a central forced-air electric air-source integrated heat pump, showing operation in space-cooling mode

Fig 5. Average 2006 selling prices for 13 SEER split system heat pumps.

(Source: www.smarterwayinc.com, 11/13/2006.)

Fig. 6. Schematic of AS-IHP system, combined space cooling and dedicated water

heating mode shown.

Fig. 7. Schematic of GS-IHP system, dedicated dehumidification mode shown.

Fig. 8. Incremental mortgage + utilities costs for $1800-\mathrm{ft}^{2} \mathrm{ZEH}$ in Atlanta (from NREL BEopt analysis).

Fig. 9. Incremental mortgage + utilities costs for $1800-\mathrm{ft}^{2} \mathrm{ZEH}$ in Houston (from NREL

BEopt analysis).

Fig. 10. Incremental mortgage + utilities costs for $1800-\mathrm{ft}^{2} \mathrm{ZEH}$ in Phoenix (from NREL

BEopt analysis).

Fig. 11. Incremental mortgage + utilities costs for $1800-\mathrm{ft}^{2} \mathrm{ZEH}$ in San Francisco (from

NREL BEopt analysis).

Fig. 12. Incremental mortgage + utilities costs for $1800-\mathrm{ft}^{2} \mathrm{ZEH}$ in Chicago (from NREL

BEopt analysis). 


\section{LIST OF TABLES}

Table 1. Estimated energy savings potential of highest-scoring electric HVAC system options for $1800-\mathrm{ft}^{2}$ NZEH (savings expressed as percent compared to central baseline), from FY05 scoping assessment (Baxter 2005) ................................................................

Table 2. Wall and ceiling cavity insulation minimum R-values, maximum window Ufactors, and SHGC for Regional Standard Practice (RSP) baseline houses

Table 3. Annual site HVAC/WH system energy use and peak for $1800 \mathrm{ft}^{2} \mathrm{RSP}$ benchmark house with Baseline HVAC/WH system

Table 4. Annual site HVAC/WH system energy use and peak for $1800-\mathrm{ft}^{2}$ NZEH house with Baseline HVAC/WH system

Table 5. Estimated annual site HVAC/WH system energy use and peak for $1800 \mathrm{ft}^{2}$ NZEH house with AS-IHP system (from Baxter 2005)

Table 6. Estimated annual site HVAC/WH system energy use and peak for $1800-\mathrm{ft}^{2}$ NZEH house with GS-IHP system (from Baxter 2005) ………........................................12

Table 7. IHP performance (by individual load) vs. baseline system in NZEH ................13

Table 8. Estimated installed costs for NZE house baseline HVAC/WH system (2006 dollars)

Table 9. Estimated installed costs for RSP house baseline HVAC/WH system (2006 dollars)

Table 10. Estimated installed costs for NZE house AS-IHP system (2006 dollars) ........21

Table 11. Estimated installed costs for NZE house GS-IHP system (2006 dollars) assuming vertical bore ground $\mathrm{HX}$ at $\$ 1000 /$ ton installed..............................................22

Table 12. Cost estimate details for GS-IHP/SWS ground HX ..........................................23

Table 13. Estimated installed costs for NZE house SWS-enhanced GS-IHP system (2006 dollars)

Table 14. Sensitivity of AS-IHP and GS-IHP system payback vs. baseline system to assumed tax credits and TOU/demand electricity pricing .25

Table 15. Postulated TOU + demand rate structure used for IHP simple payback sensitivity assessment

Table 16. Estimated PV cost savings from use of AS-IHP or GS-IHP (for space heating and cooling, water heating, and ventilation only) in a ZEH 
Table A1. HVAC longer-term option assessment scores

\section{ACKNOWLEDGEMENTS}

The author would like to acknowledge that following persons contributed significantly to the content, supporting analysis, or preparation of this report:

From Oak Ridge National Laboratory - Keith Rice, Richard Murphy, and Patrick Hughes contributed to the content and Erica Atkin to the preparation of this report. Special thanks are extended to Rebecca Moses for her assistance with estimation of the costs for the IHP systems.

From Thermal Energy System Specialists - Jeff Thornton, Tim McDowell, and David Bradley contributed to the supporting analysis. 


\section{INTRODUCTION}

The long range strategic goal of the Department of Energy's Building Technologies (DOE/BT) Program is to create, by 2020, technologies and design approaches that enable the construction of net-zero energy homes at low incremental cost (DOE/BT 2005). A net zero energy home (NZEH) is a residential building with greatly reduced needs for energy through efficiency gains, with the balance of energy needs supplied by renewable technologies. While initially focused on new construction, these technologies and design approaches are intended to have application to buildings constructed before 2020 as well resulting in substantial reduction in energy use for all building types and ages. DOE/BT's Emerging Technologies (ET) team is working to support this strategic goal by identifying and developing advanced heating, ventilating, air-conditioning, and water heating (HVAC/WH) technology options applicable to NZEHs.

Although the energy efficiency of heating, ventilating, and air-conditioning (HVAC) equipment has increased substantially in recent years, new approaches are needed to continue this trend. Dramatic efficiency improvements are necessary to enable progress toward the NZEH goals, and will require a radical rethinking of opportunities to improve system performance. The large reductions in HVAC energy consumption necessary to support the NZEH goals require a systems-oriented analysis approach that characterizes each element of energy consumption, identifies alternatives, and determines the most cost-effective combination of options. In particular, HVAC equipment must be developed that addresses the range of special needs of NZEH applications in the areas of reduced HVAC and water heating energy use, humidity control, ventilation, uniform comfort, and ease of zoning.

In FY05 ORNL conducted an initial Stage 1 (Applied Research) scoping assessment of $\mathrm{HVAC} / \mathrm{WH}$ systems options for future NZEHs to help DOE/BT identify and prioritize alternative approaches for further development. Eleven system concepts with central air distribution ducting and nine multi-zone systems were selected and their annual and peak demand performance estimated for five locations: Atlanta (mixed-humid), Houston (hothumid), Phoenix (hot-dry), San Francisco (marine), and Chicago (cold). Performance was estimated by simulating the systems using the TRNSYS simulation engine (Solar Energy Laboratory et al. 2006) in two 1800- $\mathrm{ft}^{2}$ houses - a Building America (BA) benchmark house and a prototype NZEH taken from BEopt results at the take-off (or crossover) point (i.e., a house incorporating those design features such that further progress towards ZEH is through the addition of photovoltaic power sources, as determined by current BEopt analyses conducted by NREL). Results were summarized in a project report, HVAC Equipment Design options for Near-Zero-Energy Homes - A Stage 2 Scoping Assessment, ORNL/TM-2005/194 (Baxter 2005).

The 2005 study report describes the HVAC options considered, the ranking criteria used, and the system rankings by priority. Table 1 summarizes the energy savings potential of the highest scoring options from the 2005 study for all five locations. 
Table 1. Estimated energy savings potential of highest-scoring electric HVAC system options for 1800- $\mathrm{ft}^{2} \mathrm{NZEH}$ (savings expressed as percent compared to central baseline), from FY05 scoping assessment (Baxter 2005)

\begin{tabular}{|c|c|c|c|c|c|}
\hline System & Atlanta & Houston & Phoenix & $\begin{array}{l}\text { San } \\
\text { Francisco }\end{array}$ & Chicago \\
\hline \multicolumn{6}{|c|}{ Central systems } \\
\hline $\begin{array}{l}\text { 13SEER heat pump with } 0.9 \text { EF electric } \\
\text { WH (baseline) }\end{array}$ & - & - & - & - & - \\
\hline $\begin{array}{l}18 \text { SEER 2-spd heat pump with } \\
\text { desuperheater }\end{array}$ & 21 & 23 & 31 & 20 & 25 \\
\hline GCHP with desuperheater & 26 & 22 & 24 & 21 & 30 \\
\hline $\begin{array}{l}\text { GCHP with desuperheater and solid water } \\
\text { sorbent (SWS) enhanced horizontal GHX }\end{array}$ & 26 & 22 & 24 & 21 & 30 \\
\hline 2-spd GCHP with desuperheater & 30 & 30 & 38 & 22 & 36 \\
\hline Air-source IHP & 53 & 52 & 50 & 61 & 50 \\
\hline Ground-source IHP & 58 & 56 & 55 & 62 & 58 \\
\hline \multicolumn{6}{|c|}{ Zoned systems } \\
\hline $\begin{array}{l}13 \text { SEER minisplit heat pump each zone } \\
\text { with } 0.9 \text { EF electric WH (base zoned } \\
\text { system) }\end{array}$ & 8 & 5 & 6 & 8 & 12 \\
\hline $\begin{array}{l}\text { Multisplit heat pump (MSHP) with } \\
\text { integrated demand WH module }\end{array}$ & 34 & 24 & 22 & 54 & 22 \\
\hline $\begin{array}{l}\text { MSHP with exhaust-air heat pump for } \\
\text { WH\&V }\end{array}$ & 31 & 31 & 28 & 33 & 32 \\
\hline Zoned IHP, air-source & 55 & 55 & 51 & 63 & 58 \\
\hline Zoned IHP, ground-source & 60 & 58 & 56 & 66 & 64 \\
\hline
\end{tabular}

All system options were scored by the ORNL building equipment research team and by William Goetzler of Navigant Consulting. These scores were reviewed by DOE/BT's Residential Integration program leaders and Building America team members. Based on these results, the two centrally ducted integrated heat pump (IHP) systems (air source and ground source versions) were selected for advancement to Stage 2 (Exploratory Development) business case assessments in FY06. This report describes results of these business case assessments.

\section{ASSESSMENT APPROACH}

This assessment work has involved several steps:

- Collaboration with the National Renewable Energy Laboratory (NREL) to define appropriate Regional Standard Practice (RSP) house descriptions and descriptions of identically sized prototype NZEH houses at the $50 \%+$ savings level as determined by BEopt analyses at the photovoltaic (PV) take-off point. [NOTE: savings relative to the Building America research benchmark house as of July 2005, with benchmark as defined in Hendron, et al. (2004) and Hendron (2005).] 
- Definition of baseline HVAC and water heating systems: a baseline set of equipment of legally minimum efficiency: SEER 13 and HSPF 7.7 centrally ducted split-system air-to-air heat pump for heating and cooling, a massmarket, standard dehumidifier that operates on demand when by-product latent cooling by the heat pump is insufficient, a standard electric storage water heater with energy factor of 0.90 , and mechanical ventilation system satisfying ASHRAE 62.2.

- Using computer analyses (based on TRNSYS simulations of the houses and HVAC options), the hourly space heating, space cooling (latent and sensible), ventilation, and water heating loads that will need to be met by the HVAC equipment were determined.

- Using TRNSYS analyses the energy consumption to meet the RSP and NZEH loads was determined for the baseline system and IHPs in five locations Atlanta (mixed-humid climate zone), Houston (hot-humid), Phoenix (hot-dry), San Francisco (marine), and Chicago (cold). (NOTE: only the baseline system energy consumption was computed for the RSP house.)

- The IHP options were scored against the weighted criteria factors outlined below. The quantitative analysis supported scoring of the primary should-meet criterion, which is potential to achieve peak demand and 50\% annual energy savings relative to baseline. The other criteria were scored qualitatively based on the expert opinions of the scorers.

\section{Technology Option Ranking Criteria}

The criteria consist of four must-meet criteria and ten should-meet criteria:

1. Must-meet:

a. In alignment with one of the components of strategy for achieving the HVAC and water heating objective.

b. Has potential for significant energy savings with the sum of utility and mortgage costs in new housing construction remaining the same, or enables other technologies in a whole-house package to do so.

c. Unlikely to be developed by the private sector alone.

d. Technically feasible (there is a reasonable likelihood that the product can be developed and produced).

2. Should-meet:

(The 10 criteria are each scored 1-10, criterion scores are averaged across all scoring participants, and then the criterion weights are applied to arrive at an overall project score. The best possible score is 100 .):

a. (Weight: 2.5) Equipment has the potential to achieve 50\% energy savings versus baseline in a range of climates (all climates would get best score). 
b. (Weight: 1.25) Equipment can meet ZEH energy service needs (e.g., cooling/ heating/dehumidification/fresh air ventilation/domestic hot water), which may be quite different in magnitude and relative proportions from those of current buildings, and come with additional expectations for uniform comfort and indoor environmental quality (IEQ).

c. (Weight: 1.25) There do not appear to be any high costs, such as high-cost components or other factors, that would preclude the use of the equipment in new housing construction by 2015, with the sum of utility and mortgage costs remaining the same versus baseline.

d. (Weight: 1.0) Private sector enterprises can be identified that should have an interest in the new product concept based on degree of strategic fit, competitive advantage, in-house core competencies, existing business units, market niches served, existing paths to market, entrepreneurial track record, etc.

e. (Weight: 1.0) The program element has prospects for resources of sufficient critical mass to fund early phase research and to cost-share the mid-phases in order to attract private partners for the new product concept.

f. (Weight: 0.75) Equipment is based on off-the-shelf components that are mass produced now, or are likely to become common and mass produced due to the support of markets other than NZEH (i.e., Building Technologies program resources are not expected to be needed in order for the components to reach this level of commercialization).

g. (Weight: 0.75) Equipment is easily installed and maintained without necessitating substantial additional training for installers or requiring additional trades personnel.

h. (Weight: 0.5) Equipment serves the new NZEH market but can also satisfy the conditions for participation in the broad new housing construction market for equipment.

i. (Weight: 0.5) Equipment serves the new NZEH market but can also satisfy the conditions for participation in the broad residential equipment replacement markets, including the immediacy requirement for some equipment replacements upon failure.

j. (Weight: 0.5) Equipment has the potential to achieve significant peak energy demand reduction versus baseline in a range of climates (all climates would get best score).

Failing to meet all the must-meet criteria implies "no-go." If the must-meet criteria are met numerical scores (maximum of 100) are generated based on the "should-meet" criteria. DOE/BT management, the RI program staff, and BA team members can then use the rankings and management discretion to determine whether either or both of the IHP options are "go" for further RD\&D steps. 


\section{HOUSE DESCRIPTIONS}

For the previous scoping assessment (Baxter 2005), the current Building America Research benchmark house [benchmark as defined in Hendron, et al. (2004) and Hendron (2005)] was used as the baseline house configuration. For the present study it was decided to examine a baseline house construction more indicative of typical 2006 practice. Therefore, in consultation with NREL Regional Standard Practice (RSP) house descriptions were defined. Table 2 lists the ceiling and wall cavity insulation values, window U-factors, and solar heat gain coefficients (SHGC) used in the RSP houses for each location. Requirements as outlined in the 2006 International Energy Conservation Code (IECC 2006, Table 402.1.1) were generally followed with exceptions as described in the Table 2 footnotes.

Table 2. Wall and ceiling cavity insulation minimum R-values, maximum window Ufactors, and SHGC for Regional Standard Practice (RSP) baseline houses ${ }^{a}$

\begin{tabular}{|c|c|c|c|c|c|}
\hline City & $\begin{array}{l}\text { Walls (IECC } \\
2006 \\
\text { minimum) }\end{array}$ & $\begin{array}{l}\text { Walls (values used } \\
\text { for present } \\
\text { analysis) }^{b}\end{array}$ & $\begin{array}{c}\text { Ceiling } \\
\text { (IECC } \\
2006 \\
\text { minimum) }\end{array}$ & $\begin{array}{c}\text { Window } \\
\text { U-factors } \\
\text { (IECC } \\
2006 \text { ) }\end{array}$ & $\begin{array}{c}\text { Window } \\
\text { SHGC } \\
\text { (IECC 2006) }\end{array}$ \\
\hline Atlanta & 13 & $\begin{array}{c}13 \text { cavity }+\mathrm{R} 5 \\
\text { sheathing }\end{array}$ & 30 & 0.65 & 0.40 \\
\hline Houston & 13 & $\begin{array}{c}13 \text { cavity }+\mathrm{R} 5 \\
\text { sheathing }\end{array}$ & 30 & 0.75 & 0.40 \\
\hline Phoenix & 13 & $\begin{array}{c}13 \text { cavity }+\mathrm{R} 5 \\
\text { sheathing }\end{array}$ & 30 & 0.75 & 0.40 \\
\hline $\begin{array}{c}\text { San } \\
\text { Francisco }\end{array}$ & 13 & $\begin{array}{c}13 \text { cavity }+\mathrm{R} 5 \\
\text { sheathing }\end{array}$ & 30 & 0.65 & 0.40 \\
\hline Chicago $^{c}$ & $\begin{array}{c}13 \text { cavity }+\mathrm{R} 5 \\
\text { sheathing }(2 \times 4 \\
\text { stud, } 16 \% \text { OC, } \\
25 \% \text { frame } \\
\text { factor) }\end{array}$ & $\begin{array}{c}19 \text { cavity }+\mathrm{R} 5 \\
\text { sheathing }(2 \times 6 \\
\text { stud, } 24 " \text { OC, } 20 \% \\
\text { frame factor) }\end{array}$ & $40^{d}$ & 0.35 & $\begin{array}{c}\text { No IECC } \\
\text { requirement }\end{array}$ \\
\hline
\end{tabular}

${ }^{a}$ Balance of construction (sheetrock, studs, ceiling framing factor of $11 \%$, etc., same as for BA benchmark house from 2005 study)

${ }^{b}$ IECC minimum yields lower total wall R than for BA benchmark house

${ }^{c}$ For Chicago basement wall insulation is R10 (continuous)

${ }^{\boldsymbol{d}_{\text {IECC minimum is R38 }}}$

Prototype NZEH houses were used for the IHP energy savings estimation analyses. These were as determined in July 2005 by NREL using their Building Energy Optimization (BEopt) analyses tool (Christensen 2005, Anderson, et al 2004) at the PV take-off point. Figure 1 illustrates mortgage plus utility cost results from NREL's BEopt simulation for Atlanta. The y-intercept point on the left vertical axis represents this cost parameter for the BA benchmark. The prototype NZEH for Atlanta was taken from the point on the curve at about $55 \%$ energy savings vs. the BA benchmark as indicated by the vertical dashed line. The blue solid vertical line superimposed on Figure 1 indicates the approximate energy savings of the RSP baseline house relative to the BA benchmark. 
Design cooling capacities for the houses were taken from the BEopt analyses and used to size the baseline heat pumps and the IHPs for the analyses reported in this document.

A key objective of identifying design concepts that can save up to $50 \%$ relative to current baseline systems is to move the point of break-even mortgage and utilities cost on Figure 1 from around $55-60 \%$ to $70-85 \%$ energy savings. This will in turn reduce the net cost premium required to meet the net zero energy goal.

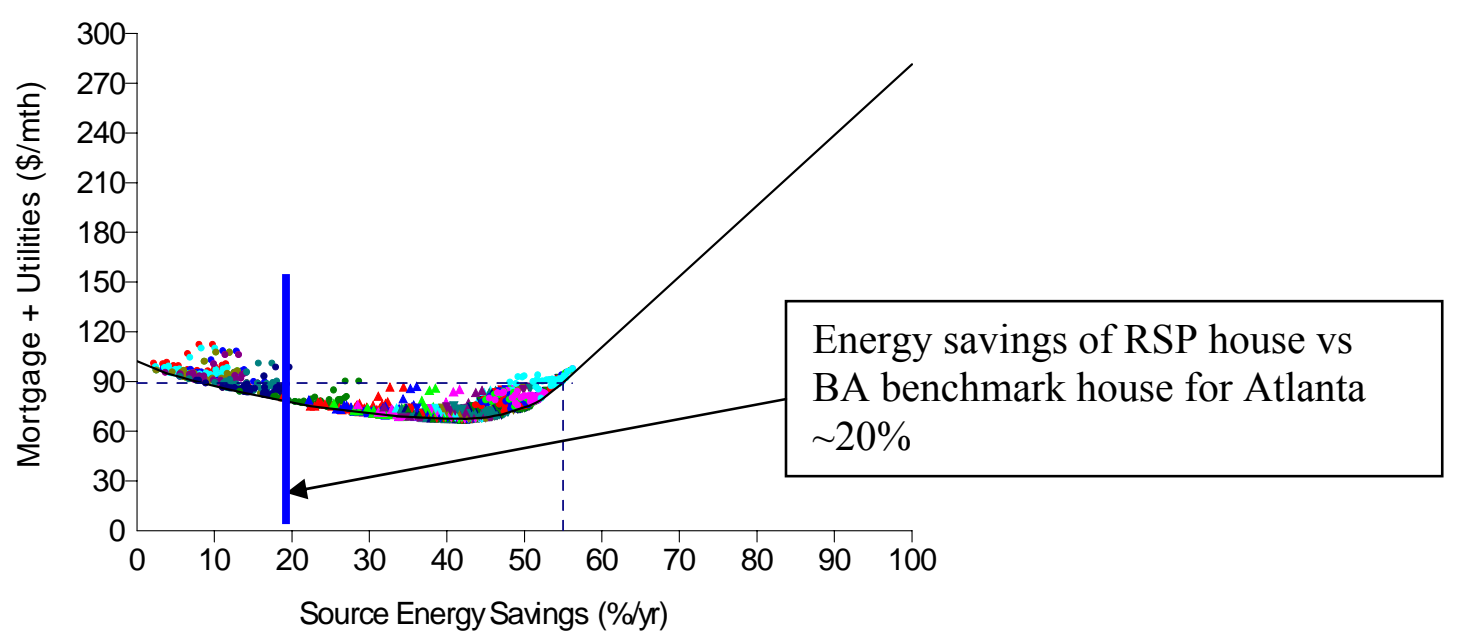

Fig. 1. Net mortgage and utilities cost vs. source energy savings for $1800-\mathrm{ft}^{2}$ house in Atlanta with BA benchmark at $0 \%$ energy savings point and prototype NZE house at $\sim 55 \%$ energy savings point (i.e., take-off point).

TRNSYS representations were developed for both the RSP and NZE houses. Thermostat temperature control was single-zone with set points of $71^{\circ} \mathrm{F}$ heating, $76^{\circ} \mathrm{F}$ cooling, and $120^{\circ} \mathrm{F}$ water heating as provided in the DOE 2.2 BDL files from NREL. In the BEopt analyses, it was assumed that the occupants of the house would open windows to take advantage of free cooling whenever ambient air temperature was low enough during the cooling season. For the TRNSYS representations we elected to do the simulations with no window openings for this analysis. We plan to investigate the impact of "free cooling" (or economizer operation) on IHP performance in FY07 using a control based on an outdoor air enthalpy sensor as opposed to window openings. Figures 2 and 3 give a comparison of the computed NZEH heating and cooling loads, respectively, from the BEopt analysis (DOE2.2-based) and from the TRNSYS analysis. In general the absolute loads computed by the TRNSYS simulation are higher for heating and lower for cooling with closer agreement (percentage-wise) where loads are higher. The trends are in close agreement. 
Additionally, active indoor humidity control was simulated in the present analyses for both the baseline system and for the IHPs. A single-zone humidistat was assumed with a $55 \%$ RH set point.

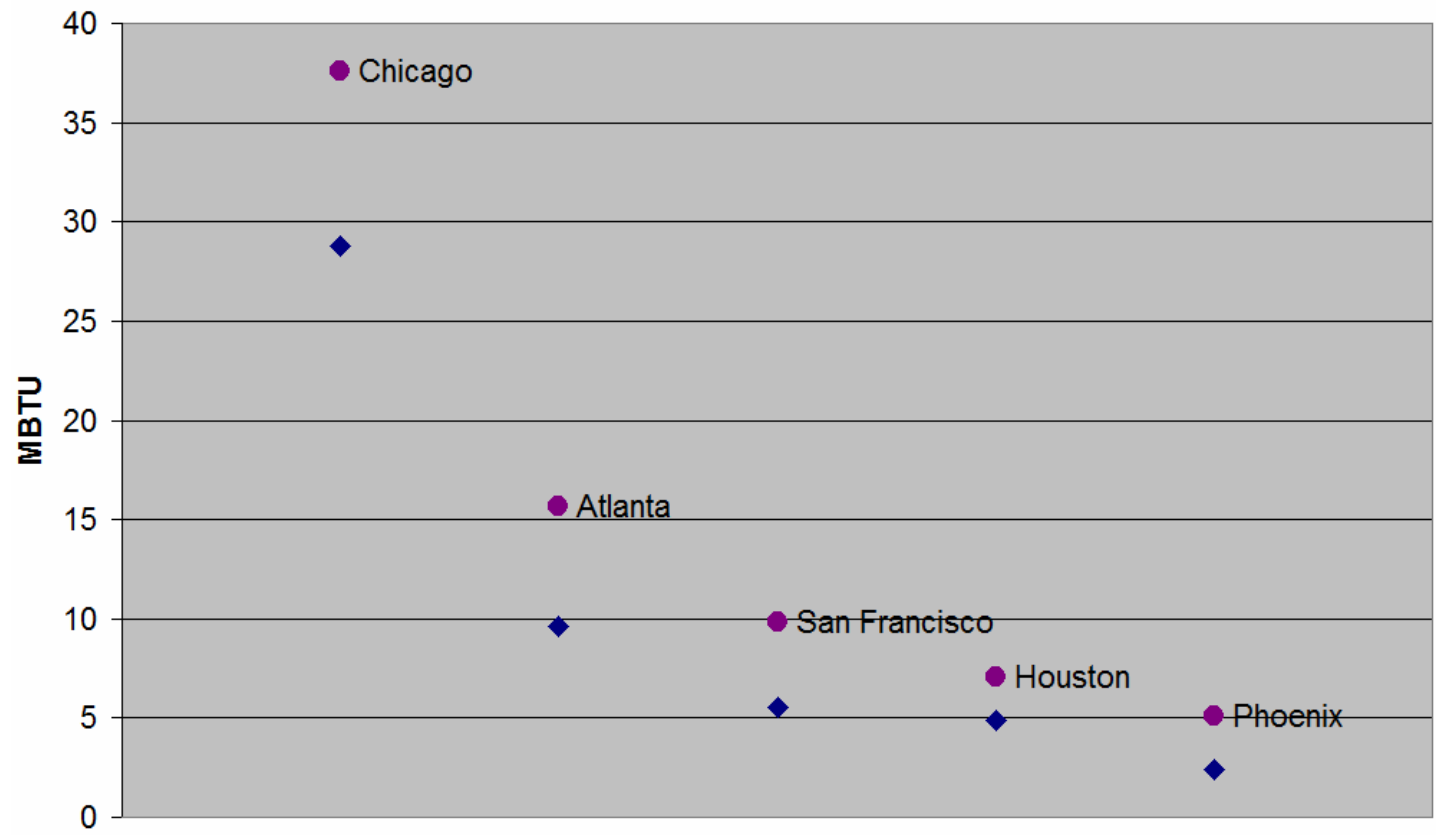

$\bullet$ DOE2 - TRNSYS

Fig. 2. DOE2 vs. TRNSYS heating loads for $1800-\mathrm{ft}^{2}$ NZEH.

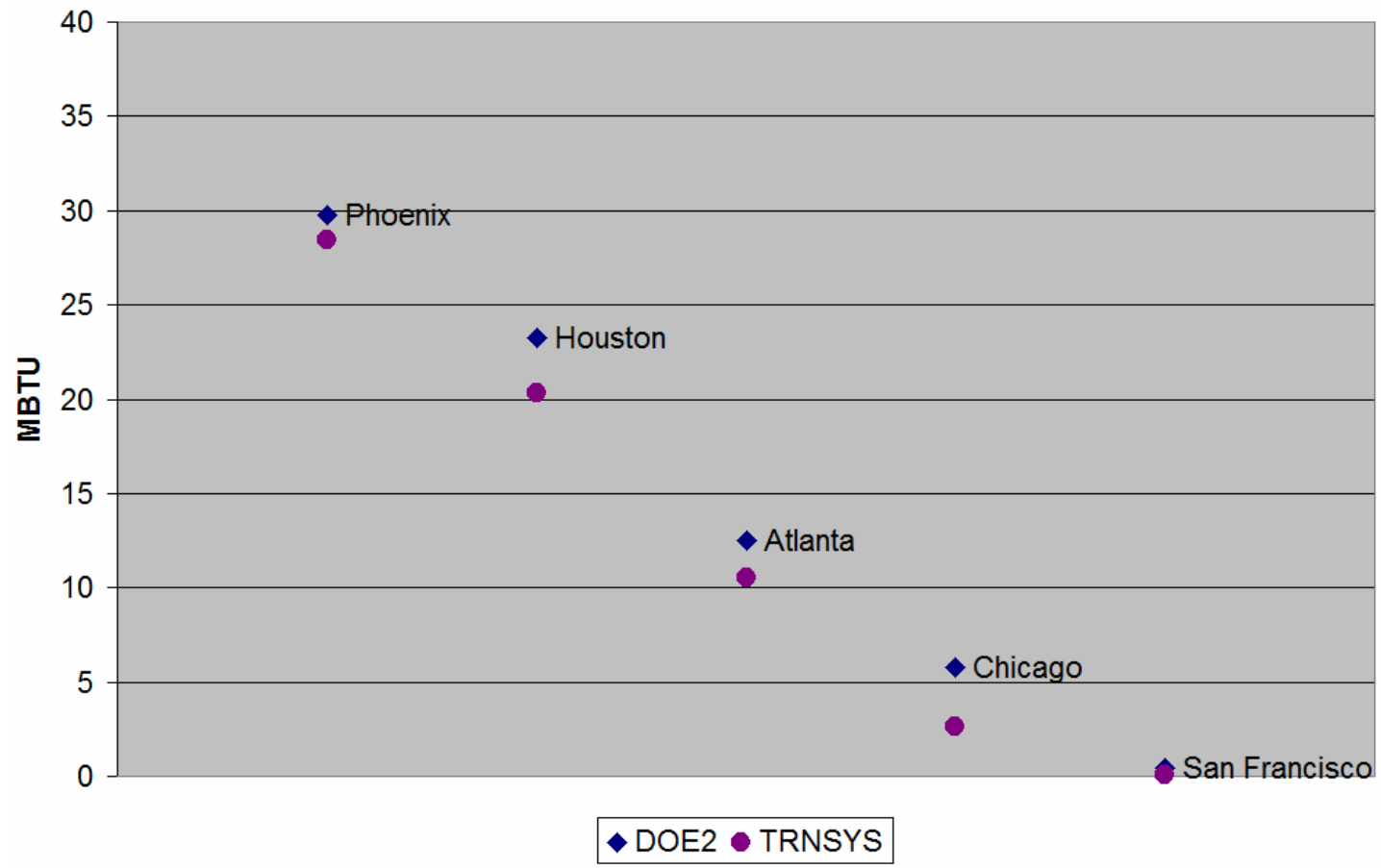

Fig. 3. DOE2 vs. TRNSYS cooling loads for $1800-\mathrm{ft}^{2}$ NZEH. 


\section{DESCRIPTION OF HVAC SYSTEM OPTIONS}

\subsection{Baseline}

A standard split-system (separate indoor and outdoor sections), air-to-air heat pump provides space heating and cooling under control of a central thermostat that senses indoor space temperature. It also provides dehumidification when operating in space cooling mode but does not separately control space humidity. Rated system efficiencies were set at the DOE-minimum required levels (SEER 13 and HSPF 7.7) in effect for 2006. Water heating is provided using a standard 50 gallon capacity electric storage water heater with energy factor $(\mathrm{EF})$ set at the current $\mathrm{DOE}-$ minimum requirement $(\mathrm{EF}=0.90)$ for this size WH. Ventilation meeting the requirements of ASHRAE Standard 62.2-2004 (ASHRAE 2004) is provided using a central exhaust fan. A separate dehumidifier (DH) is included as well to meet house dehumidification needs during times when the central heat pump is not running to provide space cooling.

Dehumidifier location, sizing, and efficiency level. Rudd, et al (2005) indicates that perhaps the most cost effective approach for adding separate dehumidification capability to a house is to locate a stand-alone dehumidifier in the conditioned space, preferably in close proximity to the main HVAC system return air grill. That is the approach adopted in the present analysis. A manufacturer of typical stand-alone DH's, Heat Controller, includes a table on their web site that suggests a 30-50 pint/day (7-12 L/d) capacity would be sufficient for a $2000 \mathrm{ft}^{2}$ house (http://www.heatcontroller.com/products/pdf/dehumidbroch.pdf). A 40 pt/d size was chosen and this proved to be adequate for the NZE house in all locations. In this case adequate was taken to mean that indoor RH levels would exceed $60 \%$ for no more than about $1-2 \%$ of the year. The $60 \%$ criterion matches that used by Rudd, et al (2005) in their study. Other studies use $65 \%$ including a recent one by Witte and Henninger (2006) for ASHRAE that evaluated humidity control capability of various unitary system designs. For the cooling set point of $76^{\circ} \mathrm{F}$ used in our analyses, ASHRAE's thermal comfort standard indicates a maximum acceptable RH of about $65 \%$ for spaces with activity levels typical of offices (Figure 5.2.1.1 in ASHRAE Standard 55-2004).

There is currently no DOE-mandated minimum efficiency value for residential dehumidifiers. However, amendments to the Energy Policy and Conservation Act (EPCA) of 1975 included in the Energy Policy Act of 2005, P.L. 109-58, expanded DOE's energy conservation program to include certain commercial equipment and residential products, including dehumidifiers. In compliance with this directive, DOE/BT has recently specified a default minimum dehumidifier energy factor $\left(\mathrm{EF}_{\mathrm{d}}\right)$ for $40 \mathrm{pt} / \mathrm{d}$ DHs of $1.3 \mathrm{~L} / \mathrm{kWh}$ effective 2007 and a default minimum of $1.4 \mathrm{~L} / \mathrm{kWh}$ effective 2012 (DOE/BT 2006). According to comments submitted by Whirlpool to EPA regarding their recent revision of the Energy Star requirements for dehumidifiers the 35-54 pt/d capacity range represents nearly $60 \%$ of all dehumidifier shipments (Hoyt 2005). DOE will focus its rulemaking 
analysis for DH's on the 35-45 pt/d size range only. The Energy Star website (http://www.energystar.gov/index.cfm?c=dehumid.pr_dehumidifiers) indicates that the current efficiency of ES-qualified dehumidifiers of the above capacity range from 1.3 to $1.5 \mathrm{~L} / \mathrm{kWh}$ (rated at $80^{\circ} \mathrm{F}$ and $60 \% \mathrm{RH}$ indoor conditions). Based on the above it was decided to use $\mathrm{EF}_{\mathrm{d}}=1.4$ for the baseline system dehumidifier efficiency in the present analysis.

\subsection{Centrally Ducted Air-Source Integrated Heat Pump (AS-IHP)}

This option is the air-source version of the integrated heat pump (IHP) currently in the breadboard laboratory prototype stage at ORNL. This concept, as shown in Figure 4, uses one variable-speed (VS) modulating compressor, two VS fans, one VS pump, and a total of four heat exchangers (HXs: two air-to-refrigerant, one water-to-refrigerant, and one air-to-water) to meet all the HVAC and water heating (WH) loads.

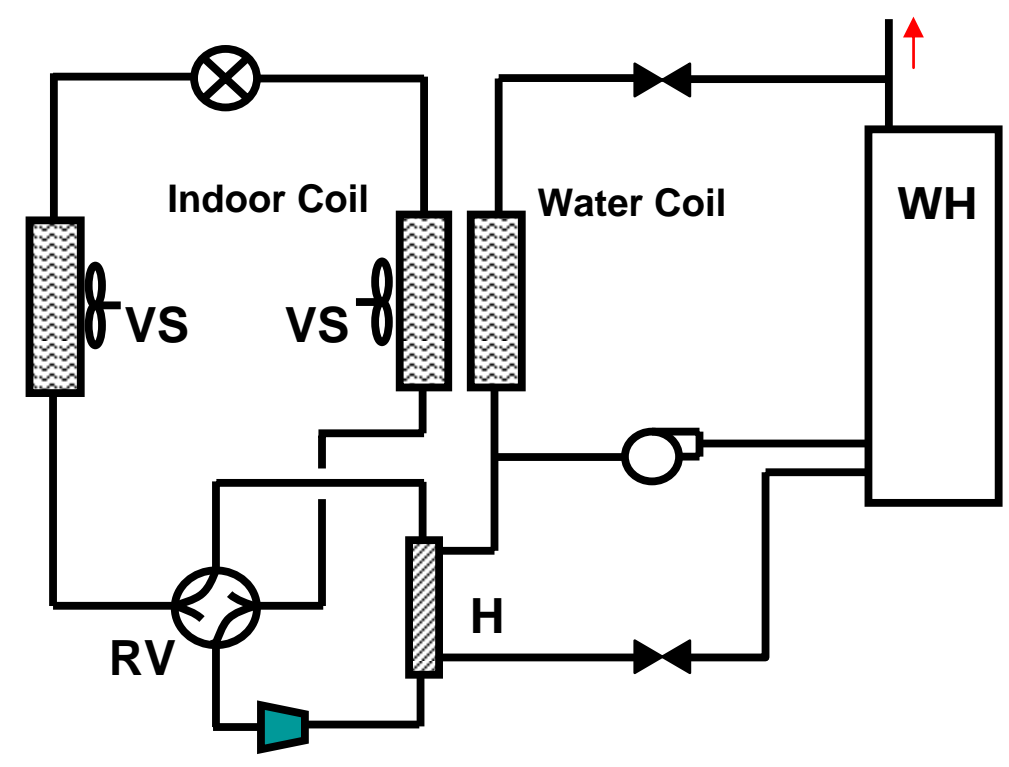

Fig. 4. Conceptual diagram of a central forced-air electric air-source integrated heat pump, showing operation in space-cooling mode.

One unique aspect is that the ventilation air is conditioned by the heat pump in both space cooling and space heating modes, and on demand if neither heating nor cooling is required. The unit also cycles on demand to dehumidify the space whether or not heating or cooling is required. The air-to-water HX uses waste hot water generated in the space cooling, dehumidification, and ventilation cooling modes to temper the ventilation air, as needed, for space neutral conditions. Compressor, indoor fan, and water pump speed modulation is used to control both indoor humidity and temperature, when needed. (Note that both water heating and ventilation air tempering can be done at the same time.) The system concept is described more fully by Tomlinson et al (2005) and Murphy eat al (2006). 
Another potentially attractive aspect of the IHP concept is that, being a single equipment package, it is better suited than the baseline suite of equipment for being able to curb demand when the grid is stressed in response to a utility or ISO radio signal.

\subsection{Centrally Ducted Ground-Source Integrated Heat Pump (GS-IHP)}

This technology is similar to the AS-IHP above but with the outdoor air coil and fan replaced with a refrigerant-to-water $\mathrm{HX}$ and secondary fluid pump connected to a conventional high-density polyethylene (HDPE) ground heat exchanger (HX), making a ground-coupled version of the IHP. As with other ground-source heat pumps the GS-IHP does not require a defrost cycle and with a properly sized ground HX operates with heat source and sink temperatures that are friendlier than outdoor air all year long. We plan to assess this option with both a vertical bore ground HX and a horizontal loop ground HX with SWS enhancement.

\section{ANALYSIS APPROACH}

The annual energy use simulations for the baseline and IHP HVAC systems were performed using the TRNSYS 16 platform (Solar Energy Laboratory, et al. 2006). This required conversion of the $1800-\mathrm{ft}^{2} \mathrm{RSP}$ house and prototype NZEH descriptions to TRNSYS Type 56 representations.

Annual, hour-by-hour simulations were performed for the baseline system for both the RSP and prototype NZEH buildings for five locations - Atlanta, mixed-humid; Houston, hot-humid; Phoenix, hot-dry; San Francisco, marine; and Chicago; cold). Annual simulations for the IHP systems were limited to the NZE houses only.

\section{SYSTEMS ENERGY CONSUMPTION RESULTS}

Table 3 provides results of the TRNSYS simulations for the baseline HVAC system for the RSP house for each of the five locations examined in this study. Table 4 provides the same information for the prototype NZEH house. Tables 5 and 6 provide results for the AS-IHP and GS-IHP, respectively. Peak kW demand in Tables 5 and 6 are hourly integrated values. Maximum peaks generally occurred in the winter. Summer peaks are generally somewhat lower and generally occurred in July or August.

Detailed results from the simulations for the NZEH are given in Table 7. The total energy consumption and consumption by individual modes for the baseline system are from the hourly TRNSYS simulations. For the IHPs the total energy consumption, that of the ventilation fan, and for the electric backup water heating and space heating are from the detailed TRNSYS simulations as well. Breakdowns for the other modes for the IHPs were from the hourly simulations as well but with adjustments to fairly charge the water pump power in combined modes to the water heating function. Temperature control for the IHPs (average indoor temperature and magnitude and duration of extreme 
high and low periods) was equal or better than for the baseline in all cities. RH control by the IHP met the criteria of no more than $1-2 \%$ of hours with $\mathrm{RH}>60 \%$ everywhere but Houston where that limit was exceeded over $15 \%$ of the time. Many of these periods occurred during mild ambient temperature periods during the heating season. Based on average DH efficiency from the detailed TRNSYS simulation we estimated $\sim 400 \mathrm{kWh}$ of energy consumption would be needed to achieve the specified level of RH control for the IHP in Houston. The IHP in Houston exceeded the $65 \%$ RH level indoors $~ 1 \%$ of hours with a maximum level of $69 \%$. $65 \% \mathrm{RH}$ is about the maximum acceptable level for thermal comfort according to ASHRAE (ASHRAE Standard 55-2004) for activity levels typical of offices. This level of activity is similar to that of most residential activities as well with the exceptions of house cleaning and cooking according to data presented in ASHRAE Standard 55-2004.

We plan to examine revised IHP control strategies for Houston to achieve the desired level of indoor humidity control in the coming year. 
Table 3. Annual site HVAC/WH system energy use and peak for $1800-\mathrm{ft}^{2}$ RSP $_{\text {benchmark }}$ house with Baseline HVAC/WH system

\begin{tabular}{|c|c|c|c|c|}
\hline Location & $\begin{array}{c}\text { Heat pump } \\
\text { cooling } \\
\text { capacity (tons) }\end{array}$ & $\begin{array}{c}\text { HVAC site } \\
\text { energy use, } \\
\mathrm{kWh}\end{array}$ & $\begin{array}{c}\text { HVAC peak } \\
\text { integrated hourly kW } \\
\text { (W/S) }\end{array}$ & $\begin{array}{c}\text { \% energy savings } \\
\text { vs. RSP/Baseline } \\
\text { HVAC }\end{array}$ \\
\hline Atlanta & 3.00 & 9,893 & $10.7 / 9.0$ & - \\
\hline Houston & 3.50 & 9,930 & $8.4 / 9.4$ & - \\
\hline Phoenix & 4.00 & 9,890 & $8.7 / 8.5$ & - \\
\hline San Francisco & 2.00 & 7,239 & $6.8 / 5.0$ & - \\
\hline Chicago & 2.25 & 11,549 & $14.4 / 8.3$ & - \\
\hline
\end{tabular}

Table 4. Annual site HVAC/WH system energy use and peak for $1800-\mathrm{ft}^{2} \mathrm{NZEH}$ house with Baseline HVAC/WH system

\begin{tabular}{|c|c|c|c|c|}
\hline Location & $\begin{array}{c}\text { Heat pump } \\
\text { cooling capacity } \\
\text { (tons) }\end{array}$ & $\begin{array}{c}\text { HVAC site } \\
\text { energy use, } \\
\mathrm{kWh}\end{array}$ & $\begin{array}{c}\text { HVAC peak } \\
\text { integrated hourly kW } \\
(\mathrm{W} / \mathrm{S})\end{array}$ & $\begin{array}{c}\% \text { energy savings } \\
\text { vs. RSP/Baseline } \\
\text { HVAC }\end{array}$ \\
\hline Atlanta & 1.25 & 7,508 & $5.9 / 4.4$ & 24.1 \\
\hline Houston & 1.25 & 8,329 & $5.9 / 4.0$ & 16.1 \\
\hline Phoenix & 1.50 & 7,123 & $6.2 / 4.4$ & 28.0 \\
\hline San Francisco & 1.00 & 4,930 & $5.6 / 4.8$ & 31.9 \\
\hline Chicago & 1.25 & 10,155 & $9.7 / 4.8$ & 12.1 \\
\hline
\end{tabular}

Table 5. Estimated annual site HVAC/WH system energy use and peak for $1800-\mathrm{ft}^{2} \mathrm{NZEH}$ house with AS-IHP system

\begin{tabular}{|c|c|c|c|c|}
\hline Location & $\begin{array}{c}\text { Heat pump } \\
\text { cooling capacity } \\
\text { (tons) }\end{array}$ & $\begin{array}{c}\text { HVAC site } \\
\text { energy use, } \\
\text { kWh }\end{array}$ & $\begin{array}{c}\text { HVAC peak } \\
\text { integrated hourly } \\
\mathrm{kW}(\mathrm{W} / \mathrm{S})\end{array}$ & $\begin{array}{c}\text { \% energy savings vs. } \\
\text { NZEH/Baseline } \\
\text { HVAC }\end{array}$ \\
\hline Atlanta & 1.25 & 3,760 & $4.6 / 1.3$ & 49.9 \\
\hline Houston & 1.25 & $3,600\left(4011^{*}\right)$ & $3.5 / 1.1$ & $56.8\left(51.8^{*}\right)$ \\
\hline Phoenix & 1.50 & 3,567 & $3.3 / 1.7$ & 49.9 \\
\hline San Francisco & 1.00 & 2,356 & $4.6 / 1.8$ & 52.2 \\
\hline Chicago & 1.25 & 6,108 & $7.2 / 1.7$ & 39.9 \\
\hline
\end{tabular}

* Estimated energy use required for RH control similar to baseline.

Table 6. Estimated annual site HVAC/WH system energy use and peak for $1800-\mathrm{ft}^{2} \mathrm{NZEH}$ house with GS-IHP system

\begin{tabular}{|c|c|c|c|c|}
\hline Location & $\begin{array}{c}\text { Heat pump } \\
\text { cooling capacity } \\
\text { (tons) }\end{array}$ & $\begin{array}{c}\text { HVAC site } \\
\text { energy use, } \\
\mathrm{kWh}\end{array}$ & $\begin{array}{c}\text { HVAC peak } \\
\text { integrated hourly } \\
\mathrm{kW}(\mathrm{W} / \mathrm{S})\end{array}$ & $\begin{array}{c}\text { \% energy savings vs. } \\
\text { NZEH/Baseline } \\
\text { HVAC }\end{array}$ \\
\hline Atlanta & 1.25 & 3,435 & $4.5 / 1.3$ & 54.3 \\
\hline Houston & 1.25 & $3,419\left(3,827^{*}\right)$ & $3.9 / 1.0$ & $59.0\left(54.1^{*}\right)$ \\
\hline Phoenix & 1.50 & 3,176 & $3.2 / 1.3$ & 55.4 \\
\hline San Francisco & 1.00 & 2,505 & $4.8 / 1.8$ & 49.2 \\
\hline Chicago & 1.25 & 5,662 & $7.6 / 1.8$ & 44.2 \\
\hline
\end{tabular}

* Estimated energy use required for RH control similar to baseline. 
Table 7. IHP performance (by individual load) vs. baseline system in NZEH

\begin{tabular}{|c|c|c|c|c|c|c|}
\hline \multirow{2}{*}{\multicolumn{2}{|c|}{$\begin{array}{c}\text { Loads (1800 } \mathrm{ft}^{2} \text { NZEH from } \\
\text { TRNSYS) }\end{array}$}} & \multicolumn{5}{|c|}{ Equipment } \\
\hline & & \multirow{2}{*}{$\begin{array}{c}\text { Baseline } \\
\text { Energy use, } \\
\text { kWh }\left(I^{2} r\right)\end{array}$} & \multicolumn{2}{|c|}{ AS-IHP } & \multicolumn{2}{|c|}{ GS-IHP } \\
\hline Source & kWh & & $\begin{array}{l}\text { Energy use, } \\
\text { kWh }\left(I^{2} r\right)\end{array}$ & $\begin{array}{c}\text { Energy } \\
\text { reduction } \\
\text { compared to } \\
\text { baseline }\end{array}$ & $\begin{array}{l}\text { Energy use, } \\
\text { kWh }\left(I^{2} r\right)\end{array}$ & \begin{tabular}{|c|}
$\begin{array}{c}\text { Energy } \\
\text { reduction } \\
\text { compared to } \\
\text { baseline }\end{array}$ \\
\end{tabular} \\
\hline \multicolumn{7}{|c|}{ Atlanta } \\
\hline Space Heating & 4381 & 1597 & 1285 & $19.5 \%$ & 958 & $40.0 \%$ \\
\hline Space Cooling & 5770 & 2069 & 1398 & $32.4 \%$ & 1294 & $37.5 \%$ \\
\hline Water Heating & 3032 & 3380 & $1046(411)$ & $69.1 \%$ & $1131(570)$ & $66.5 \%$ \\
\hline Dedicated DH & 208 & 273 & 38 & $86.1 \%$ & 33 & $87.9 \%$ \\
\hline Ventilation fan & - & 189 & 20 & $89.4 \%$ & 19 & $89.9 \%$ \\
\hline Totals & 13391 & 7508 & 3760 & $49.9 \%$ & 3435 & $54.3 \%$ \\
\hline \multicolumn{7}{|c|}{ Houston } \\
\hline Space Heating & 1700 & 616 & 540 & $12.3 \%$ & 391 & $36.5 \%$ \\
\hline Space Cooling & 10093 & 3652 & 1810 & $50.4 \%$ & 1805 & $50.6 \%$ \\
\hline Water Heating & 2505 & 2813 & 1028 (199) & $63.4 \%$ & $1015(246)$ & $63.9 \%$ \\
\hline Dedicated DH $^{1}$ & 855 & 1059 & 620 & $41.4 \%$ & 604 & $43.0 \%$ \\
\hline Ventilation fan & - & 189 & 13 & $93.1 \%$ & 12 & $93.7 \%$ \\
\hline Totals & 15153 & 8329 & 4011 & $51.8 \%$ & 3827 & $54.1 \%$ \\
\hline \multicolumn{7}{|c|}{ Phoenix } \\
\hline Space Heating & 1428 & 479 & 362 & $24.4 \%$ & 270 & $43.6 \%$ \\
\hline Space Cooling & 9987 & 3985 & 2483 & $37.7 \%$ & 2267 & $43.1 \%$ \\
\hline Water Heating & 2189 & 2470 & $689(68)$ & $72.1 \%$ & $606(67)$ & $75.5 \%$ \\
\hline Dedicated DH & - & - & - & - & - & - \\
\hline Ventilation fan & - & 189 & 33 & $82.5 \%$ & 33 & $82.5 \%$ \\
\hline Totals & 13604 & 7123 & 3567 & $49.9 \%$ & 3176 & $55.4 \%$ \\
\hline \multicolumn{7}{|c|}{ San Francisco } \\
\hline Space Heating & 2816 & 896 & 751 & $16.2 \%$ & 736 & $17.9 \%$ \\
\hline Space Cooling & 86 & 32 & 26 & $18.8 \%$ & 23 & $25.0 \%$ \\
\hline Water Heating & 3387 & 3766 & $1544(749)$ & $59.0 \%$ & $1716(1001)$ & $54.4 \%$ \\
\hline Dedicated DH & 37 & 47 & 3 & $93.6 \%$ & 2 & $95.7 \%$ \\
\hline Ventilation fan & - & 189 & 32 & $83.1 \%$ & 28 & $85.2 \%$ \\
\hline Totals & 6326 & 4930 & 2356 & $52.2 \%$ & 2505 & $49.2 \%$ \\
\hline \multicolumn{7}{|c|}{ Chicago } \\
\hline Space Heating & 10404 & $4678(875)$ & $4000(358)$ & $14.5 \%$ & $3369(137)$ & $28.0 \%$ \\
\hline Space Cooling & 2541 & 908 & 488 & $46.3 \%$ & 424 & $53.3 \%$ \\
\hline Water Heating & 3807 & 4218 & $1544(907)$ & $63.4 \%$ & $1804(1161)$ & $57.2 \%$ \\
\hline Dedicated DH & 127 & 162 & 60 & $63.0 \%$ & 51 & $68.5 \%$ \\
\hline Ventilation fan & - & 189 & 16 & $91.5 \%$ & 14 & $92.6 \%$ \\
\hline Totals & 16879 & 10155 & 6108 & $39.9 \%$ & 5662 & $44.2 \%$ \\
\hline
\end{tabular}

${ }^{1}$ IHPs include additional energy consumption estimates to achieve $\sim$ same level of RH control as baseline in Houston - $411 \mathrm{kWh}$ for AS-IHP; $408 \mathrm{kWh}$ for GS-IHP.

The results summarized in Tables 5-7 show that the IHPs meet (or very nearly meet) the $50 \%$ savings goal in all locations examined in this study except Chicago. There the energy service loads are dominated by heating. Space heating $(\mathrm{SH})$ and water heating (WH) together constitute $\sim 84 \%$ of the total load. In addition system heating efficiency suffers, particularly for the AS-IHP during the extremely cold temperatures encountered 
in this climate. A large fraction of the WH load was met by the electric resistance elements in the water tank $(907 \mathrm{kWh}$ for the AS version and $1161 \mathrm{kWh}$ for the GS version). Backup electric resistance energy for space heating totaled $358 \mathrm{kWh}$ for the AS-IHP and $137 \mathrm{kWh}$ for the GS-IHP. We examined increased system size (1.5 and 1.75 ton nominal cooling capacity) for the AS-IHP and found that the amount of electric backup space heating decreased for the IHP but also for the baseline system so net savings remained at $\sim 40 \%$.

Examination of Table 7 shows a significant fraction of the WH mode energy consumption is due to the backup electric elements in most of the locations, particularly for Chicago as noted above and for San Francisco as well. Most of this back up element usage occurs in winter when the $\mathrm{WH}$ function is competing with the $\mathrm{SH}$ function for available system heating capacity. This is particularly disadvantageous for the heating dominated locations. For the TRNSYS simulations summarized above, we assumed a control approach that assigned first priority to space heating during winter operation. There is clearly room for IHP efficiency improvement if an optimized control approach can reduce some or all of the WH backup element use while not compromising space temperature control. An initial attempt to modify the control strategy for the Chicago and San Francisco cases yielded some encouraging results - backup electric WH down significantly and overall energy use down such that energy savings vs. the baseline went up significantly - from $52.2 \%$ and $49.2 \%$ for AS and GS, respectively to $56.3 \%$ and $55.6 \%$ in San Francisco; and from 39.9\% and $44.2 \%$ to $41.8 \%$ and $47.2 \%$ in Chicago. We plan to examine alternative controls options to further optimize WH mode operation in the coming year.

Winter peak $\mathrm{kW}$ ranged from about $20 \%$ to $65 \%$ lower for the IHPs than for the baseline. Cooling peaks ranged from about $60 \%$ to $75 \%$ lower.

Individual system efficiencies needed to reach annual energy savings goal: A reasonable question to ask is "How efficient must individual pieces of equipment be to achieve the $50 \%$ energy savings goal?" The best available efficiencies for the individual units that compose the baseline system (sans the ventilation fan) are as follows.

Central air conditioners/heat pumps - A recent $A C H \& R$ News article noted that at least one central $\mathrm{AC}$ product was available with a rated SEER of 23 for a unit with variable-speed compressor (ACH\&R News 2006). A search of ARI's online directory found six split system heat pump models (all ductless-type products) with certified HSPF ratings of 10 or higher (www.aridirectory.org/index.html; accessed August 16, 2006). No heat pump products were found in the directory with both a 23 SEER and HSPF $\geq 10$.

Water heaters - An integral-type (heat pump components mounted to water storage tank) heat pump water heater (HPWH) product marketed in the early 2000's achieved a rated EF of 2.4 (www.ecrinternational.com/secure/upload/ document/76.pdf). The maker has removed this product from the market recently. 
Dehumidifiers - The Energy Star website

(www.energystar.gov/index.cfm?c=dehumid.pr dehumidifiers) notes one standalone $\mathrm{DH}$ product with an $\mathrm{EF}_{\mathrm{d}}$ of 2.0 (50 pt/d capacity).

Applying these efficiencies to the NZE house loads and estimating the resulting energy consumption yields about $42.5 \%$ annual energy savings vs. the baseline system suite in Atlanta. To reach the $50 \%$ target savings level with a suite of individual equipment will thus require that efficiency of one or more of the individual units be increased. One combination of unit efficiency levels that would accomplish this would be a HPWH with an EF of 3, a DH with $\mathrm{EF}_{\mathrm{d}}$ of 3, and a variable-capacity heat pump with 23 SEER and 10 HSPF. A suite of equipment with these efficiencies could yield about $51 \%$ annual savings for the Atlanta location. It would also exceed the 50\% target in Houston (53\%), Phoenix (51\%), and San Francisco (57\%). It would just reach the target in Chicago $(50 \%)$ assuming the heat pump has enough over-capacity capability during winter to offset the need for electric resistance backup heating (doubtful based on the TRNSYS AS-IHP simulation results discussed above). To achieve the HPWH and DH efficiencies noted would require a significant RD\&D effort to develop small-capacity, fractionalhorsepower compressors with much higher efficiency than available today.

Alternatively, central heat pumps (of 1-1.5 ton nominal capacity) must be developed with much higher SEER and HSPF ratings than commercially available today. Assuming a suite of equipment that includes the best available HPWH and DH efficiencies noted above, my estimate is that the central heat pump would have to have rated SEER and HSPF of 33 and 15 , respectively, to ensure meeting the $50 \%$ savings target in four of the five study locations (Chicago would be doubtful based on AS-IHP results noted above). The IHP energy savings estimates are based on demonstrated efficiency of a laboratory proof-of-concept prototype that used commercially available, variable-capacity compressor technology being manufactured in large quantities today.

\section{SYSTEM COST ESTIMATES}

\subsection{Baseline System Estimated Costs}

Central heat pump; minimum estimate: From the 2002 technical support document (TSD/heat pump) for DOE's central heat pump efficiency standards (DOE/BT 2002), the estimated cost to manufacture a 13 SEER 3-ton split system heat pump in 1998 dollars was $\$ 743.36$. Data from the US Department of Labor indicates that the Producer Price Index (PPI) for finished goods less food and energy has inflated by $10.8 \%$ from 1998 to 2006. Applying this factor to the 1998 cost estimate yields an estimated cost to manufacture of \$823.64 in 2006 dollars. The TSD/heat pump also estimated mark up factors for manufacturer, distributor, and dealer of $1.23,1.26$, and 1.27 , respectively. Applying these factors to the manufacturing cost estimate yields an estimated selling price for a 3-ton heat pump of $\$ 1621.13$ (2006 dollars). Pricing data obtained on May 16, 2006 from the Smarterway.com web site (www.smarterwayinc.com/), a source used by NREL in obtaining cost data for BEopt analyses, indicates that 1.5 ton systems are on 
average about $80.5 \%$ of the cost of 3 -ton models. So, an estimate for the selling price of a 1.5 ton heat pump is $\$ 1305.01$ in 2006 dollars.

Central heat pump; maximum estimate: Average pricing data for twelve (12) different manufacturers' brands from the Smarterwayinc.com site is plotted in Figure 5 for 13 SEER heat pumps from 1.5 - 4.0 tons nominal cooling capacity. Price increases approximately linearly with capacity above the 2-ton level. Below this level the price reduces much less rapidly, beginning to show asymptotic behavior. Prices for 1.0 and 1.25 ton sizes are estimated based on this assumption. It is assumed that these prices include manufacturer, distributor and dealer mark ups.

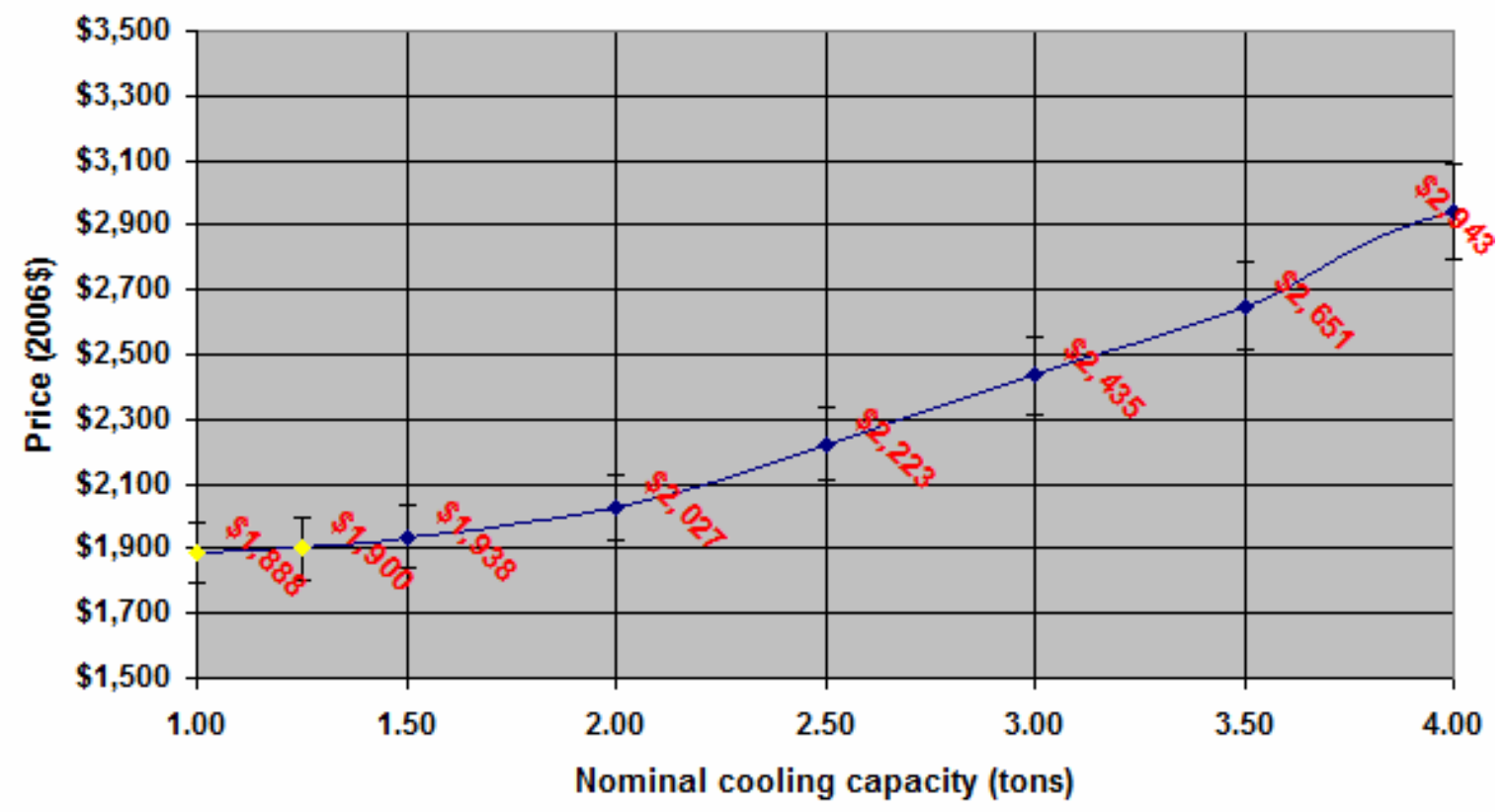

Fig 5. Average 2006 selling prices for 13SEER split system heat pumps. (Source: www.smarterwayinc.com, 11/13/2006.)

Central heat pump; installation cost estimate: The TSD/heat pump estimated average 1998 installation costs for a central heat pump of $\$ 2280$ with no differentiation for size. The Consumer Price Index (for all items less food and energy) was used to inflate this cost to 2006 dollars. Between 1998 and 2006 the CPI has increased about 18.3\%, thus the estimated installation cost for a baseline central heat pump in 2006 dollars is about $\$ 2690$.

Water heater: From the 2000 technical support document (TSD/WH) for DOE's water heater efficiency standards (DOE/BT 2000), the estimated cost to manufacture a 50gallon electric storage water heater in 1998 dollars was $\$ 166.60$. This cost includes the following efficiency enhancement features needed to reach the prescribed efficiency level: a heat trap, 2.5" of foam insulation, and foam insulation on the tank bottom. Applying the 1998-2006 PPI of 1.108 (above), the estimated manufacturing cost is $\$ 184.60$ in 2006 dollars. The TSD/WH estimated an overall mark up factor of 1.7 for manufacturer to consumer which yields an estimated selling price of $\$ 313.82$ in 2006 
dollars. 1998 installation costs estimated in the TSD/WH are \$160, and after inflating using the 1998-2006 CPI (above) this yields an installation cost of \$188.8 in 2006 dollars. The overall estimated cost to the consumer for a 50-gallon storage electric water heater in 2006 dollars is therefore $\$ 502.62$.

Dehumidifier: Costs for a $50 \mathrm{pt} / \mathrm{d}$ stand-alone dehumidifier are estimated at $\$ 400$ (2001 dollars) based on data presented by Rudd, et al. (2005). This includes cost of the dehumidifier, an overflow drain pan, and running a condensate line to nearest drain. The CPI inflated by an estimated 10\% for the period from 2001 to 2006 (U.S. Dept. of Labor) so this cost would be $\$ 440$ in 2006 dollars. The web site of "AC for sale" (http://acforsale.com), another source of cost data for BEopt, includes recent prices for dehumidifiers to enable estimation of the relative cost of a $40 \mathrm{pt} / \mathrm{d}$ model compared to the $50 \mathrm{pt} / \mathrm{d}$ size. Based on this data, stand-alone $40 \mathrm{pt} / \mathrm{d}$ dehumidifier cost in 2006 dollars is estimated to be about $\$ 415$.

Ventilation fan: The minimum continuous ventilation rate for an $1800 \mathrm{ft}^{2}\left(167 \mathrm{~m}^{2}\right)$ house with three bedrooms is $48 \mathrm{cfm}$ per ASHRAE Standard 62.2-2004 (ASHRAE 2004). A typical 50-cfm exhaust fan ducted to the nearest exterior wall is assumed to be used to provide this function, with makeup air provided by infiltration through the building envelope. RSMeans Mechanical Cost Data (Means 2005) indicates that the installed cost of this item (assuming $4 \mathrm{ft}$ of 6-inch-diameter duct and exterior weather cap) in 2005 dollars is about $\$ 300$. Since the CPI increase from January 2005 to January 2006 was about $1.9 \%$, the cost in 2006 dollars would be about $\$ 305$.

Total baseline HVAC/WH/DH system cost estimate: Table 8 provides the baseline system costs for the NZEH at each of the five locations used in this study. Table 9 provides similar cost estimates for baseline systems for the RSP houses.

Table 8. Estimated installed costs for NZE house baseline HVAC/WH system (2006 dollars)

\begin{tabular}{|c|c|c|c|c|c|c|c|}
\hline City & $\begin{array}{c}\text { Heat pump } \\
\text { nominal cooling } \\
\text { capacity (tons) }\end{array}$ & $\begin{array}{c}\text { DH } \\
\text { size } \\
(\mathrm{pts} / \mathrm{d})\end{array}$ & $\begin{array}{c}\text { Heat pump } \\
\text { cost }\end{array}$ & $\begin{array}{c}\mathrm{DH} \\
\text { cost }\end{array}$ & $\begin{array}{c}\text { WH } \\
\text { cost }\end{array}$ & $\begin{array}{c}\text { Vent } \\
\text { fan } \\
\text { cost }\end{array}$ & Total cost \\
\hline Atlanta & 1.25 & 40 & $\$ 3985-4590$ & $\$ 415$ & $\$ 503$ & $\$ 305$ & $\$ 5208-5813$ \\
\hline Houston & 1.25 & 40 & $\$ 3985-4590$ & $\$ 415$ & $\$ 503$ & $\$ 305$ & $\$ 5208-5813$ \\
\hline Phoenix & 1.50 & 40 & $\$ 3995-4628$ & $\$ 415$ & $\$ 503$ & $\$ 305$ & $\$ 5218-5851$ \\
\hline $\begin{array}{c}\text { San } \\
\text { Francisco }\end{array}$ & 1.00 & 40 & $\$ 3974-4578$ & $\$ 415$ & $\$ 503$ & $\$ 305$ & $\$ 5197-5801$ \\
\hline Chicago & 1.25 & 40 & $\$ 3985-4590$ & $\$ 415$ & $\$ 503$ & $\$ 305$ & $\$ 5208-5813$ \\
\hline
\end{tabular}

Table 9. Estimated installed costs for RSP house baseline HVAC/WH system (2006 dollars)

\begin{tabular}{|c|c|c|c|c|c|c|c|}
\hline City & $\begin{array}{c}\text { Heat pump } \\
\text { nominal cooling } \\
\text { capacity (tons) }\end{array}$ & $\begin{array}{c}\text { DH } \\
\text { size } \\
\text { (pts/d) }\end{array}$ & $\begin{array}{c}\text { Heat pump } \\
\text { cost }\end{array}$ & $\begin{array}{c}\text { DH } \\
\text { cost }\end{array}$ & $\begin{array}{c}\text { WH } \\
\text { cost }\end{array}$ & $\begin{array}{c}\text { Vent } \\
\text { fan } \\
\text { cost }\end{array}$ & Total cost \\
\hline Atlanta & 3.00 & 40 & $\$ 4311-5125$ & $\$ 415$ & $\$ 503$ & $\$ 305$ & $\$ 5534-6348$ \\
\hline Houston & 3.50 & 40 & $\$ 4509-5341$ & $\$ 415$ & $\$ 503$ & $\$ 305$ & $\$ 5807-6564$ \\
\hline
\end{tabular}




\begin{tabular}{|c|c|c|c|c|c|c|c|}
\hline Phoenix & 4.00 & 40 & $\$ 4649-5633$ & $\$ 415$ & $\$ 503$ & $\$ 305$ & $\$ 5872-6856$ \\
\hline $\begin{array}{c}\text { San } \\
\text { Francisco }\end{array}$ & 2.00 & 40 & $\$ 4009-4717$ & $\$ 415$ & $\$ 503$ & $\$ 305$ & $\$ 5232-5940$ \\
\hline Chicago & 2.25 & 40 & $\$ 4106-4815$ & $\$ 415$ & $\$ 503$ & $\$ 305$ & $\$ 5329-6038$ \\
\hline
\end{tabular}

\subsection{AS-IHP Cost Estimate}

An artist's concept of the AS-IHP system is given in Figure 6. The basic heat pump system (compressor, indoor and outdoor coils, indoor blower, outdoor fan, refrigerant piping, flow controls, etc.) is similar to the baseline heat pump. While three separate sections (indoor air handler, outdoor coil, and compressor section) are shown in Figure 6, the system could conceivably be packaged in two sections like conventional split system heat pumps and air conditioners. To complete the IHP system, a water heater (with backup electric elements \& controls), a refrigerant/water heat exchanger (for water heating), a multi-speed hot water circulation pump, connecting piping between the water heater and heat pump, a water/air heat exchanger coil (for tempering heating during dehumidification operation), two water flow control valves (for tempering water flow and water heating operation), a return air damper, and a short duct with motorized damper for ventilation air are added to the basic heat pump.

Cost estimates for each of these elements were developed as described below. Where costs were estimated using Means (2005) they have been inflated to 2006 dollars by the factor of 1.019 (increase in the CPI from January 2005 to January 2006).

1. For the basic heat pump, the author obtained relative costs between a SEER 13 system and a SEER 18 system in the process of replacing his own home heat pump. The SEER 18 unit included dual compressors and a variable-speed indoor blower and its installed cost excluding ductwork was about 1.8 times that of the SEER 13 unit (same manufacturer). Since the IHP system would include a single variable-speed compressor and variable-speed indoor and outdoor fans, thus requiring three inverter speed controllers, we estimated that a split system heat pump with these same features would be twice the cost of the base 13 SEER system - $\$ 2610$ to $\$ 3876$ for a 1.5 ton system.

2. The water heater tank for the IHP was assumed to be identical to that used in the baseline system, and with the same installed cost - $\$ 503$.

3. Prices for refrigerant/water heat exchangers (R-W HX in figure 6) were obtained from a major water-source heat pump manufacturer (Ellis 2006). Quantity costs for high-efficiency heat exchangers to a WSHP OEM were estimated at \$180 each by the manufacturer. To obtain an estimate of the cost to the consumer as assembled into the IHP package the markup factors for manufacturer, distributor, and dealer from the TSD/heat pump (DOE/BT 2002) were assumed to apply. Total estimated cost for this item is $\$ 355$ as assembled into the IHP package. 


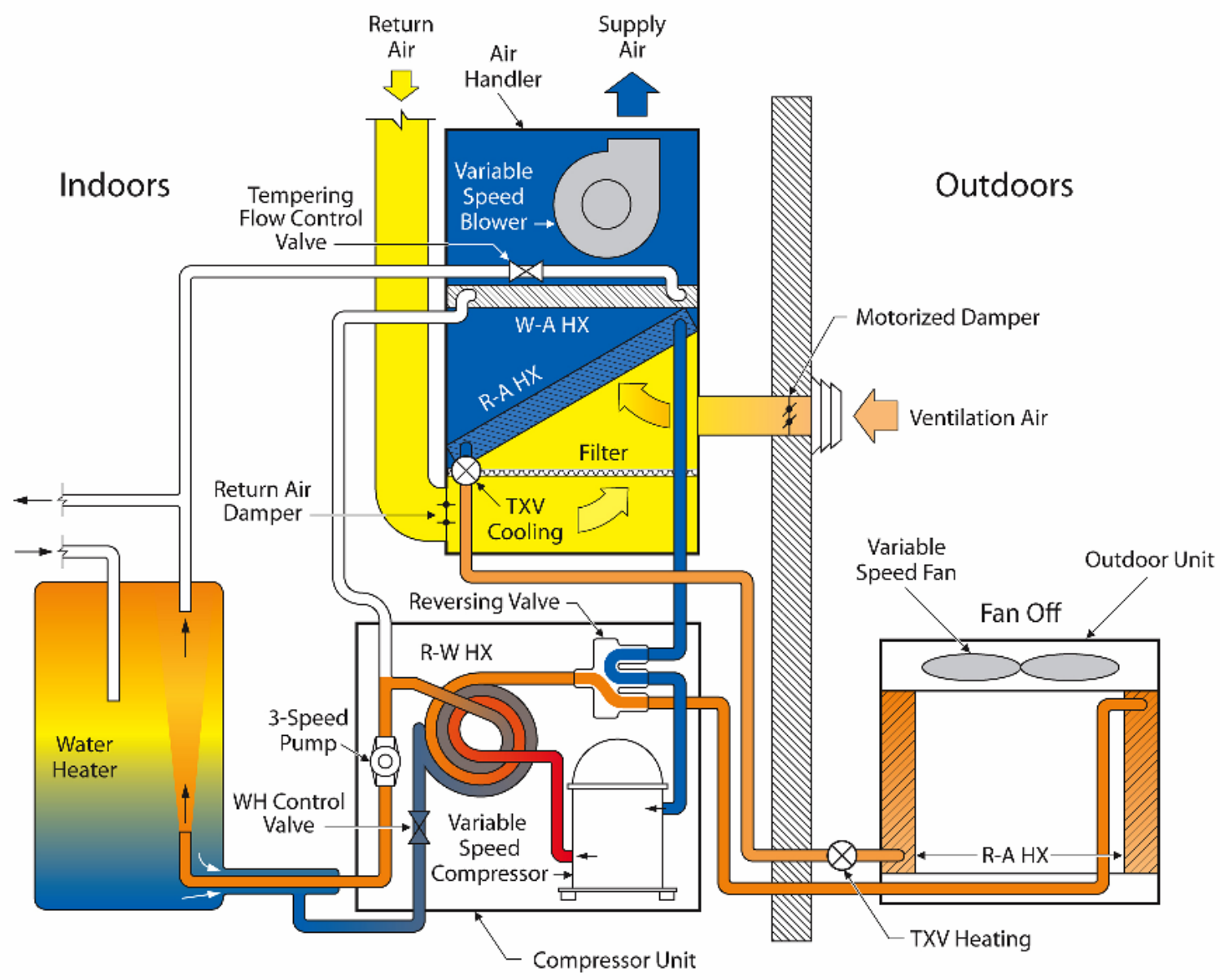

Fig. 6. Schematic of AS-IHP system, combined space cooling and demand water heating mode shown.

4. The cost of the multi-speed hot water circulating pump in quantity was estimated to be about $\$ 60$ based on the price quoted for a replacement pump for our laboratory IHP prototype and input from Ellis (2006). The markup factors from the TSD/heat pump were assumed to apply giving an estimated cost to consumer of $\$ 118$ as assembled into the IHP package.

5. It is assumed that the WH tank and heat pump would be installed in very close proximity so that minimal interconnecting water tubing runs would be required. Based on data in Means (2005) and assuming that a total of $50 \mathrm{ft}$ of $3 / 4$ inch insulated plastic pipe (suitable for water temperatures over $155^{\circ} \mathrm{F}$ ) would be required, cost of installing the water piping including connections to the tank and heat pump unit is estimated at $\$ 525$. This further assumes that an OEM could purchase the materials for the piping at a 50\% quantity discount from the Means unit prices.

6. Water/air heat exchanger (W-A HX in Figure 6) costs were estimated based on input obtained from HeatCraft, Inc., makers of this item for the lab prototype IHP system. Their estimated pricing for 300 units was $\$ 32.67$ each in $2006 \$$ reflecting current copper and aluminum commodity prices (Hutchins 2006). The markup 
factors from the TSD/heat pump were applied to this manufacturer cost yielding a total estimated cost of about $\$ 64$ as assembled into the IHP package.

7. For the WH control valve item, a water solenoid valve similar to the ASCO "red hat ${ }^{\circledR}$ " product was assumed. ASCO's list price for this item is about $\$ 160$ for $1 / 2$ inch or $3 / 4$ inch sizes and they indicated an OEM ordering in quantity could get them for about half this amount, or $\$ 80$ (ASCO 2006). Applying the markup factors from the TSD/heat pump gives an estimated cost to the consumer as assembled into the IHP package of $\$ 157$.

8. The tempering water control valve would be a variable-position type as specified by Murphy, et al. (2006) and its function is to control hot water flow to the WA HX coil during dedicated DH operation to assure that air leaves the ID blower section at the summer temperature set point of $76^{\circ} \mathrm{F}$ and no higher. Means (2005) price data for an electric motor controlled valve, inflated to $\$ 2006$ is about $\$ 210$. We assume that an OEM buying in large quantities could get this item for $\$ 105$. With the TSD/heat pump markup factors applied, price to the consumer as assembled into the IHP package would be about \$207.

9. For the vent line with motorized damper and exterior weather cap, cost data from Means (assuming a 2-foot long, 6 inch diameter line) resulted in a cost estimate for the basic materials of about $\$ 102$. We assume that an OEM buying in large quantities could get these items for $\$ 51$. With the TSD/heat pump markup factors applied, price to the consumer would be about $\$ 100$.

10. For the return air damper, a motorized damper of 16 " by 12 " size is assumed. This size was chosen to keep the main return and supply air duct velocities below the maximum limits for $600 \mathrm{cfm}$ (1.5 ton design capacity) design flow as specified by ACCA Manual D (ACCA 1995). The cost of this size damper from Means (2005) is about $\$ 122$ in 2006\$. We assume that an OEM buying in large quantities could get this item for $\$ 61$. With the TSD/heat pump markup factors applied, price to the consumer as assembled into the IHP package would be about $\$ 120$.

11. Installation of the basic heat pump was assumed to be the same as that of the baseline system SEER 13 heat pump, but an increase to $\$ 3000$ was assumed to cover miscellaneous contingencies in the IHP case.

Estimated installed costs for the AS-IHP system in each city are given in Table 10. In comparison, Thorne (1998) noted an installed cost range for integrated heat pumps (space conditioning and water heating functions only) of $\$ 4,325-\$ 5,875$ in 1998 dollars (costs include $\$ 475$ for the electric water heater tank). This equates to about $\$ 5,100-\$ 6,950$ in 2006 dollars using the 1998-2006 CPI increase of 1.183. Also, included in Table 10 are estimated energy cost savings along with estimated simple payback periods vs. the baseline system in the ZEH. 
Table 10. Estimated installed costs for NZE house AS-IHP system (2006 dollars)

\begin{tabular}{|c|c|c|c|c|c|c|c|c|}
\hline City & \multirow{2}{*}{$\begin{array}{c}\text { Heat pump } \\
\text { capacity } \\
\text { (tons) }\end{array}$} & \multicolumn{2}{|c|}{ Total cost } & \multicolumn{2}{|c|}{$\begin{array}{c}\text { Premium over baseline } \\
\text { system }\end{array}$} & $\begin{array}{c}\text { Energy } \\
\text { cost } \\
\text { savings }\end{array}$ & $\begin{array}{c}\text { Simple payback } \\
\text { over baseline } \\
\text { system, years }\end{array}$ \\
\cline { 3 - 9 } & & low & high & low & high & & low & high \\
\hline Atlanta & 1.25 & $\$ 7,745$ & $\$ 8,949$ & $\$ 2,537$ & $\$ 3,136$ & $\$ 327$ & 7.8 & 9.6 \\
\hline Houston & 1.25 & $\$ 7,745$ & $\$ 8,949$ & $\$ 2,537$ & $\$ 3,136$ & $\$ 460$ & 5.5 & 6.8 \\
\hline Phoenix & 1.50 & $\$ 7,759$ & $\$ 9,025$ & $\$ 2,541$ & $\$ 3,174$ & $\$ 319$ & 8.0 & 10.0 \\
\hline San Francisco & 1.00 & $\$ 7,731$ & $\$ 8,925$ & $\$ 2,534$ & $\$ 3,124$ & $\$ 308$ & 8.2 & 10.1 \\
\hline Chicago & 1.25 & $\$ 7,745$ & $\$ 8,949$ & $\$ 2,537$ & $\$ 3,136$ & $\$ 342$ & 7.4 & 9.2 \\
\hline
\end{tabular}

The energy cost savings for each city in Table 10 were calculated based on the most recent, 2006, electricity rates as implemented into BEopt (Spencer, 2006) - \$0.0872/kWh for Atlanta, $\$ 0.108 / \mathrm{kWh}$ for Houston, $\$ 0.0896 / \mathrm{kWh}$ for Phoenix, $\$ 0.1196 / \mathrm{kWh}$ for San Francisco, and $\$ 0.0844 / \mathrm{kWh}$ for Chicago.

\subsection{GS-IHP Cost Estimate}

An artist's concept for the GS-IHP system is shown in Figure 7. Cost for the basic heat pump portion of the GS-IHP (with a refrigerant/water heat exchanger and multi-speed pump replacing the outdoor air coil and variable-speed fan, but with outdoor fan/coil enclosure, refrigerant line set, and defrost cycle with its associated controls all eliminated) was assumed to be $10 \%$ less than that for the AS-IHP above. Costs for items 2-10 in the above list were assumed to be identical as for the AS-IHP. Installation of the GS-IHP (exclusive of the ground HX) should be somewhat less involved than for the ASIHP since there would be no outdoor fan/coil enclosure (eliminates need for labor/materials for the mounting pad, setting the enclosure on the pad, and installation of the associated electrical power/control wiring and refrigerant line set). Installation costs for the GS-IHP package were therefore estimated to be $15 \%$ less than for the AS-IHP, or $\$ 2550$. For the vertical bore ground HX option, the installed cost of the ground heat exchanger (including hookup to the GS-IHP package) was estimated at $\$ 1000 /$ ton based on input from a large, experienced installation contractor (Schoen 2006). Total system cost estimates for each city are given in Table 11. Estimated energy cost savings and simple paybacks are included. 


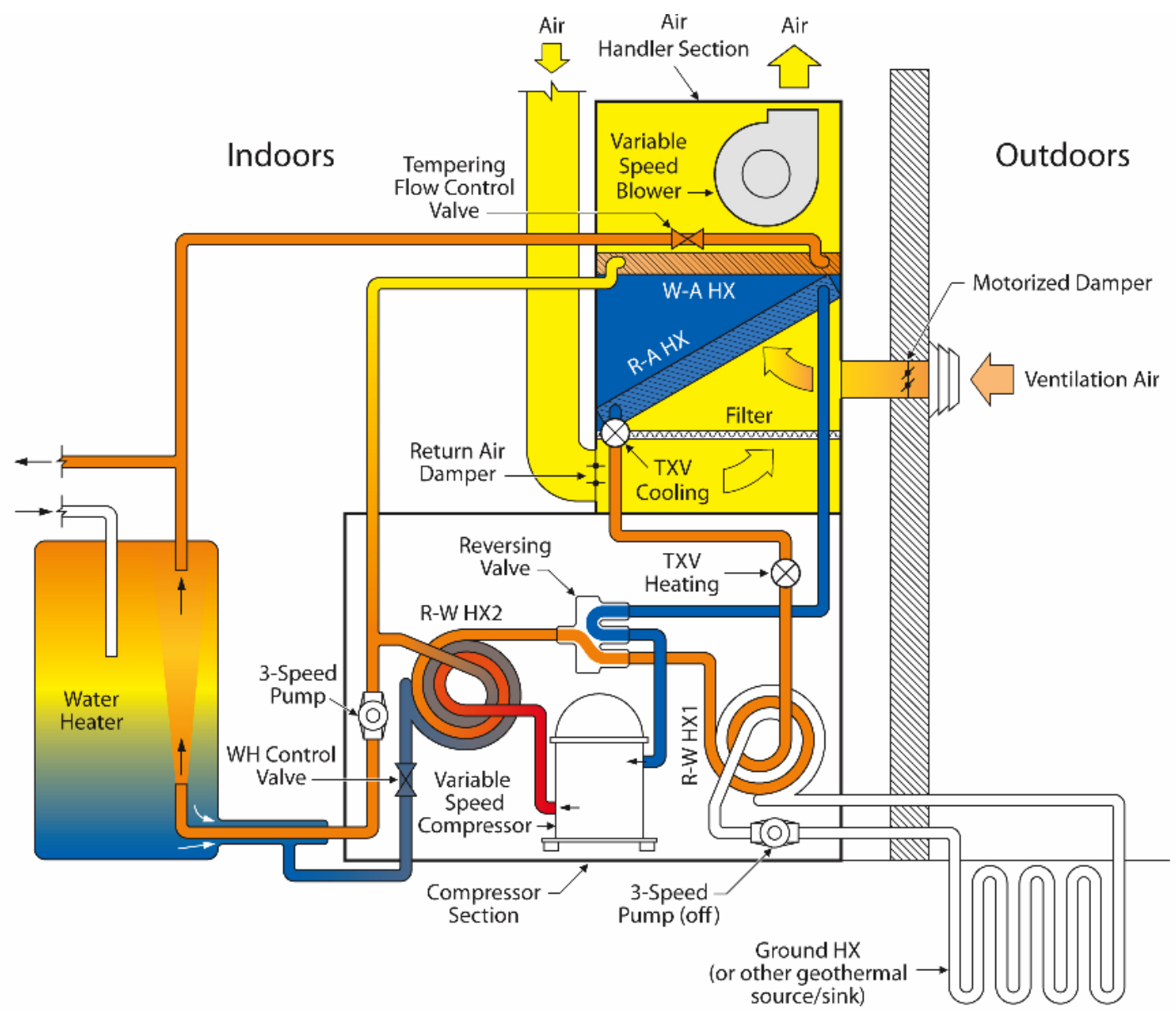

Fig. 7. Schematic of GS-IHP system, dedicated dehumidification mode shown.

Table 11. Estimated installed costs for NZE house GS-IHP system (2006 dollars) -

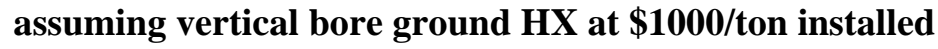

\begin{tabular}{|c|c|c|c|c|c|c|c|c|}
\hline City & $\begin{array}{c}\text { Heat pump } \\
\text { capacity } \\
\text { (tons) }\end{array}$ & \multicolumn{2}{|c|}{ Total cost } & \multicolumn{2}{|c|}{$\begin{array}{c}\text { Premium over } \\
\text { baseline system }\end{array}$} & $\begin{array}{c}\text { Energy cost } \\
\text { savings }\end{array}$ & \multicolumn{2}{|c|}{$\begin{array}{c}\text { Simple payback } \\
\text { over baseline } \\
\text { system, years }\end{array}$} \\
\cline { 3 - 9 } & & low & high & low & high & & low & high \\
\hline Atlanta & 1.25 & $\$ 8,280$ & $\$ 9,369$ & $\$ 3,331$ & $\$ 3,936$ & $\$ 355$ & 8.6 & 10.0 \\
\hline Houston & 1.25 & $\$ 8,280$ & $\$ 9,369$ & $\$ 3,331$ & $\$ 3,936$ & $\$ 486$ & 6.3 & 7.3 \\
\hline Phoenix & 1.50 & $\$ 8,548$ & $\$ 9,687$ & $\$ 3,591$ & $\$ 4,224$ & $\$ 354$ & 9.4 & 10.8 \\
\hline San Francisco & 1.00 & $\$ 8,010$ & $\$ 9,097$ & $\$ 3,070$ & $\$ 3,674$ & $\$ 290$ & 9.7 & 11.4 \\
\hline Chicago & 1.25 & $\$ 8,280$ & $\$ 9,369$ & $\$ 3,331$ & $\$ 3,936$ & $\$ 379$ & 8.1 & 9.4 \\
\hline
\end{tabular}

\subsection{GS-IHP/SWS Cost Estimate}

The solid-water-sorbent- (SWS) enhanced environmental coupling concept (Ally 2006a) is being investigated for its potential to reduce the size (and cost) of the ground HX required for the GS-IHP. Results of field experiments conducted at a research house in 
the Lenoir City, TN Habitat for Humanity $(\mathrm{HfH})$ site indicate that a horizontal ground HX of about $700 \mathrm{ft}$ of $3 / 4$ inch HDPE pipe surrounded by $80 \mathrm{lb}$ of SWS material and 3200 lb of water enclosed in a vapor barrier surrounding the pipe would be sufficient to handle the peak heat rejection load from a 1-ton heat pump system. A $1200-\mathrm{ft}^{2} \mathrm{HfH}$ house (30 $\mathrm{ft}$ by $40 \mathrm{ft}$ footprint) at the site has a conventional ground-coupled heat pump with a horizontal loop ground HX of $1500 \mathrm{ft}$ of $3 / 4$-inch HDPE that was installed completely within the excavation needed for the house foundation. The HX pipe length was determined per design by Bob Brown of WaterFurnace (Brown 2006). Thus the test results indicate that use of the SWS could potentially reduce the required HX length for that house by a factor of two. A horizontal HX enhanced with the SWS material should fit comfortably within the available foundation and utility service trench length for the ZEH's used in this study (30-ft by $30-\mathrm{ft}$ footprint).

The results further indicate that the performance of the SWS-enhanced heat exchanger in the experiment is achieving heat transfer efficiency equivalent to that of soil with a thermal conductivity seven times greater than the native soil at the site (Ally 2006b).

Parametric analyses conducted as part of the FY05 scoping study (Baxter 2005) indicated that SWS enhancement equivalent to a thermal conductivity increase of $10-15$ times greater than native soil would be needed to achieve energy efficiency equal to that of a vertical loop ground HX. This would require doubling the amounts of SWS material and water to $160 \mathrm{lb}$ and $6400 \mathrm{lb}$, respectively, for a 1-ton system. It is further assumed for purposes of this study that the ground HX peak heat rejection capacity could be doubled again by doubling the SWS and water (to $320 \mathrm{lb}$ SWS and 12,800 lb water) enabling the $\mathrm{HX}$ length to be cut in half. Using these assumptions together with HDPE pipe costs of $\$ 0.21 / \mathrm{ft}$ (Schoen 2006), SWS costs of $\$ 0.69 / \mathrm{lb}$ (Ally 2006b), and vapor barrier costs of \$25 (Ally 2006b) a rough estimate of an SWS-enhanced GS-IHP system was developed. Details of the cost estimate are given in Table 12.

Table 12. Cost estimate details for GS-IHP/SWS ground HX

\begin{tabular}{|c|c|c|c|c|c|}
\hline $\begin{array}{c}\text { Cooling capacity } \\
\text { Tons }\end{array}$ & $\begin{array}{c}\text { SWS } \\
\text { lb/cost }\end{array}$ & $\begin{array}{c}\text { HDPE pipe } \\
\text { length, ft/cost }\end{array}$ & $\begin{array}{c}\text { HX installation } \\
\text { cost }\end{array}$ & $\begin{array}{c}\text { Vapor barrier } \\
\text { cost }\end{array}$ & $\begin{array}{c}\text { Total } \\
\text { cost }\end{array}$ \\
\hline 1 (San Francisco) & $160 / \$ 110$ & $700 / \$ 147$ & $\$ 455$ & $\$ 25$ & $\$ 737$ \\
& $320 / \$ 221$ & $350 / \$ 74$ & $\$ 228$ & & $\$ 548$ \\
\hline 1.25 (Atlanta, Houston, & $200 / \$ 138$ & $900 / \$ 189$ & $\$ 585$ & $\$ 25$ & $\$ 937$ \\
Chicago) & $400 / \$ 276$ & $450 / \$ \$ 94$ & $\$ 293$ & & $\$ 688$ \\
\hline 1.5 (Phoenix) & $240 / \$ 166$ & $1100 / \$ 231$ & $\$ 715$ & $\$ 25$ & $\$ 1137$ \\
& $480 / \$ 331$ & $550 / \$ 116$ & $\$ 358$ & & $\$ 830$ \\
\hline
\end{tabular}

The HX installation cost in Table 12 is based on $\$ 0.65 / \mathrm{ft}$ and was arrived at as follows. The 1500-ft HDPE HX in the HfH house noted above cost $\$ 1500$ to install (Christian 2006). This included laying and headering three 500-ft pipe loops in the trench, installing a pump, connecting the pump and HX to the heat pump, and leak checking the HX. The loop contractor was from Blountville, Tennessee, approximately 120 miles from the job site, and made three trips to the site. For purposes of this estimate it was assumed that a local contractor could do the job in one day, saving three round trips or 720 miles of travel. DOE allows business travelers to claim $\$ 0.445 /$ mile for personal car mileage, so 
at this rate $\$ 320$ could be deducted from the cost. The GS-IHP package is assumed to include the ground loop pump so no expense for pump purchase and installation is required. \$200 is deducted from the cost to cover elimination of pump cost and labor for mounting, connecting HDPE piping, and making electrical power and control connections. This reduces the installation cost estimate to $\$ 980$, or $\$ 0.65 / \mathrm{ft}$ based on the $1500-\mathrm{ft}$ installation at $\mathrm{HfH}$. This is assumed to cover the cost of laying the plastic vapor barrier in the trench, laying and headering the pipe, adding the SWS material and water, covering the pipe and SWS-water mixture with the plastic vapor barrier, and securing the vapor barrier. Since we assume the pipe is laid in the house foundation and/or utility service trenches, trench backfilling is not charged to the ground HX.

Total system cost estimates for each city are given in Table 13 assuming the maximum SWS usage (least pipe length). If, as we believe, the assumed level of ground HX enhancement can be achieved with the SWS backfill the GS-IHP costs could be reduced to about the same level as for the AS-IHP. Estimated energy cost savings and simple paybacks are included.

Table 13. Estimated installed costs for NZE house SWS-enhanced GS-IHP system (2006 dollars)

\begin{tabular}{|c|c|c|c|c|c|c|c|c|}
\hline \multirow[t]{2}{*}{ City } & \multirow[t]{2}{*}{$\begin{array}{l}\text { Heat pump } \\
\text { capacity } \\
\text { (tons) }\end{array}$} & \multicolumn{2}{|c|}{ Total cost } & \multicolumn{2}{|c|}{$\begin{array}{c}\text { Premium over } \\
\text { baseline system }\end{array}$} & \multirow[t]{2}{*}{$\begin{array}{l}\text { Energy cost } \\
\text { savings }\end{array}$} & \multicolumn{2}{|c|}{$\begin{array}{c}\text { Simple payback } \\
\text { over baseline } \\
\text { system, years }\end{array}$} \\
\hline & & low & high & low & high & & low & high \\
\hline Atlanta & 1.25 & $\$ 7,718$ & $\$ 8,807$ & $\$ 2,510$ & $\$ 2,994$ & $\$ 355$ & 7.1 & 8.4 \\
\hline Houston & 1.25 & $\$ 7,718$ & $\$ 8,807$ & $\$ 2,510$ & $\$ 2,994$ & $\$ 486$ & 5.2 & 6.2 \\
\hline Phoenix & 1.50 & $\$ 7,878$ & $\$ 9,017$ & $\$ 2,660$ & $\$ 3,166$ & $\$ 354$ & 7.5 & 9.0 \\
\hline San Francisco & 1.00 & $\$ 7,558$ & $\$ 8,645$ & $\$ 2,361$ & $\$ 2,844$ & $\$ 290$ & 8.1 & 9.8 \\
\hline Chicago & 1.25 & $\$ 7,718$ & $\$ 8,807$ & $\$ 2,510$ & $\$ 2,994$ & $\$ 379$ & 6.6 & 7.9 \\
\hline
\end{tabular}

\subsection{Cost Sensitivities}

The simple paybacks in Tables 10, 11, and 13 assume no favorable tax incentives or utility rate structures designed to promote use of IHPs or other highly efficient HVAC/WH system options. An estimate of the sensitivity of IHP payback vs. the base system to these factors was developed for two levels of tax incentive and a postulated time-of-use (TOU) + demand charge utility rate structure.

Early in 2006, the Internal Revenue Service issued guidelines for a new, two-year program of tax incentives for energy conservation (http://www.irs.gov/newsroom/article/0,,id=154657,00.html). These incentives include a $\$ 300$ tax credit to home owners for purchase of "energy efficient property" including airsource heat pumps which have a minimum SEER of 15, HSPF of 9, and rated EER at $95^{\circ} \mathrm{F}\left(\mathrm{EER}_{95}\right)$ of 13 . Based on the AS-IHP lab system tests last year (Tomlinson 2005), it's estimated SEER and HSPF are 17.9 and 11.3, respectively, both well in excess of the rebate requirements. IHP peak reduction potential during peak cooling season was 
estimated at $60-75 \%$ from the analyses summarized in Section 6 of this report. In comparison, the average EER E5 $_{5}$ of single-speed heat pump models with 13 SEER is 11.3 according to Southern California Edison (2005) in their Database for Energy Efficiency Resources (DEER) study for the California Energy Commission (CEC). So the $13 \mathrm{EER}_{95}$ requirement represents about a $6 \%$ peak efficiency improvement or peak power reduction on average (12 vs. 11.3). Again the projected peak reduction for the IHP is well in excess of this requirement. With a $\$ 300$ credit, simple paybacks for the IHP systems reduce by $0.6-1.0$ years depending upon location. If the credit could be increased to $\$ 1000$, paybacks would fall by $2-3$ years. These results are summarized in Table 14.

Table 14. Sensitivity of AS-IHP and GS-IHP system payback vs. baseline system to assumed tax credits and TOU/demand electricity pricing

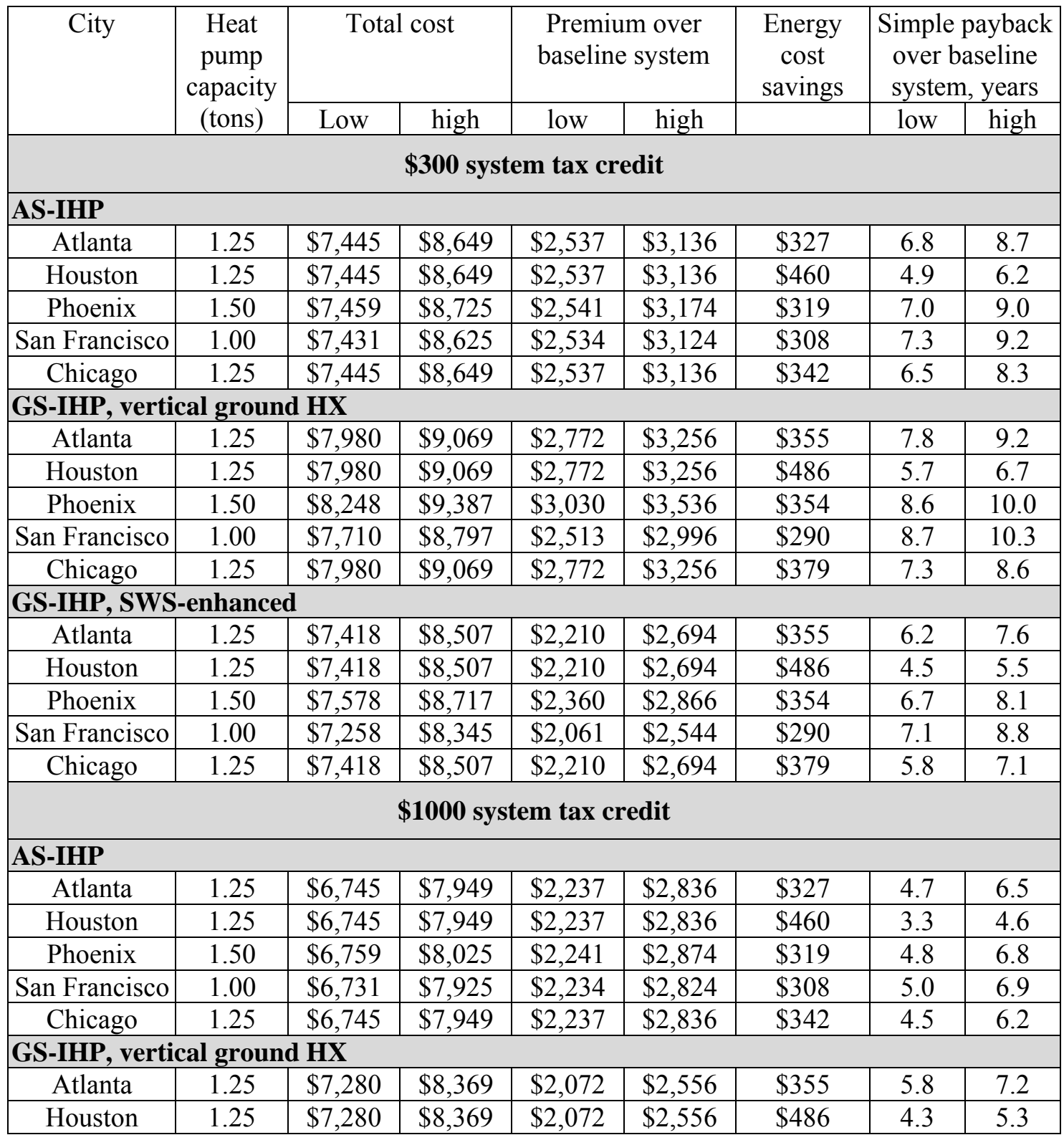




\begin{tabular}{|c|c|c|c|c|c|c|c|c|}
\hline Phoenix & 1.50 & $\$ 7,548$ & $\$ 8,687$ & $\$ 2,330$ & $\$ 2,836$ & $\$ 354$ & 6.6 & 8.0 \\
\hline San Francisco & 1.00 & $\$ 7,010$ & $\$ 8,097$ & $\$ 1,813$ & $\$ 2,296$ & $\$ 290$ & 6.3 & 7.9 \\
\hline Chicago & 1.25 & $\$ 7,280$ & $\$ 8,369$ & $\$ 2,072$ & $\$ 2,556$ & $\$ 379$ & 5.5 & 6.7 \\
\hline \multicolumn{9}{|c|}{ GS-IHP, SWS-enhanced } \\
\hline Atlanta & 1.25 & $\$ 6,718$ & $\$ 7,807$ & $\$ 1,510$ & $\$ 1,994$ & $\$ 355$ & 4.3 & 5.6 \\
\hline Houston & 1.25 & $\$ 6,718$ & $\$ 7,807$ & $\$ 1,510$ & $\$ 1,994$ & $\$ 486$ & 3.1 & 4.1 \\
\hline Phoenix & 1.50 & $\$ 6,878$ & $\$ 8,017$ & $\$ 1,660$ & $\$ 2,166$ & $\$ 354$ & 4.7 & 6.1 \\
\hline San Francisco & 1.00 & $\$ 6,558$ & $\$ 7,645$ & $\$ 1,361$ & $\$ 1,844$ & $\$ 290$ & 4.7 & 6.4 \\
\hline Chicago & 1.25 & $\$ 6,718$ & $\$ 7,807$ & $\$ 1,510$ & $\$ 1,994$ & $\$ 379$ & 4.0 & 5.3 \\
\hline \multicolumn{9}{|c|}{$\$ 1000$ system tax credit + TOU/demand rates } \\
\hline \multicolumn{9}{|l|}{ AS-IHP } \\
\hline Atlanta & 1.25 & $\$ 6,745$ & $\$ 7,949$ & $\$ 1,537$ & $\$ 2,136$ & $\$ 624$ & 2.5 & 3.4 \\
\hline Houston & 1.25 & $\$ 6,745$ & $\$ 7,949$ & $\$ 1,537$ & $\$ 2,136$ & $\$ 884$ & 1.7 & 2.4 \\
\hline Phoenix & 1.50 & $\$ 6,759$ & $\$ 8,025$ & $\$ 1,541$ & $\$ 2,174$ & $\$ 667$ & 2.3 & 3.3 \\
\hline San Francisco & 1.00 & $\$ 6,731$ & $\$ 7,925$ & $\$ 1,534$ & $\$ 2,124$ & $\$ 485$ & 3.2 & 4.4 \\
\hline Chicago & 1.25 & $\$ 6,745$ & $\$ 7,949$ & $\$ 1,537$ & $\$ 2,136$ & $\$ 575$ & 2.7 & 3.7 \\
\hline \multicolumn{9}{|c|}{ GS-IHP, vertical ground HX } \\
\hline Atlanta & 1.25 & $\$ 7,280$ & $\$ 8,369$ & $\$ 2,072$ & $\$ 2,556$ & $\$ 629$ & 3.3 & 4.1 \\
\hline Houston & 1.25 & $\$ 7,280$ & $\$ 8,369$ & $\$ 2,072$ & $\$ 2,556$ & $\$ 899$ & 2.3 & 2.8 \\
\hline Phoenix & 1.50 & $\$ 7,548$ & $\$ 8,687$ & $\$ 2,330$ & $\$ 2,836$ & $\$ 745$ & 3.1 & 3.8 \\
\hline San Francisco & 1.00 & $\$ 7,010$ & $\$ 8,097$ & $\$ 1,813$ & $\$ 2,296$ & $\$ 462$ & 3.9 & 5.0 \\
\hline Chicago & 1.25 & $\$ 7,280$ & $\$ 8,369$ & $\$ 2,072$ & $\$ 2,556$ & $\$ 628$ & 3.3 & 4.1 \\
\hline \multicolumn{9}{|c|}{ GS-IHP, SWS-enhanced } \\
\hline Atlanta & 1.25 & $\$ 6,718$ & $\$ 7,807$ & $\$ 1,510$ & $\$ 1,994$ & $\$ 629$ & 2.4 & 3.2 \\
\hline Houston & 1.25 & $\$ 6,718$ & $\$ 7,807$ & $\$ 1,510$ & $\$ 1,994$ & $\$ 899$ & 1.7 & 2.2 \\
\hline Phoenix & 1.50 & $\$ 6,878$ & $\$ 8,017$ & $\$ 1,660$ & $\$ 2,166$ & $\$ 745$ & 2.2 & 2.9 \\
\hline San Francisco & 1.00 & $\$ 6,558$ & $\$ 7,645$ & $\$ 1,361$ & $\$ 1,844$ & $\$ 462$ & 2.9 & 4.0 \\
\hline Chicago & 1.25 & $\$ 6,718$ & $\$ 7,807$ & $\$ 1,510$ & $\$ 1,994$ & $\$ 628$ & 2.4 & 3.2 \\
\hline
\end{tabular}

To estimate the potential impact of a TOU + demand utility costs, a rate structure was postulated as shown in Table 15. The TOU rate itself is patterned after a residential structured that was in use on a trial basis in Laredo, TX in the early 1990's (Goldman, et al, 1995). A demand charge of $\$ 10 /$ peak $\mathrm{kW} /$ month was added to the TOU hourly use rates for purposes of this present sensitivity analysis. Applying this postulated rate structure to the baseline and IHP ZEH systems in the five study locations yielded increased annual energy cost savings. Table 14 includes simple payback impacts from combining the TOU + demand rates with a $\$ 1000$ tax credit. In this scenario, simple paybacks for the IHP ranged from about $2-5$ years depending upon location.

Table 15. Postulated TOU + demand rate structure used for IHP simple payback sensitivity assessment

\begin{tabular}{|c|c|c|c|}
\hline Season & Time of day & Rate as fraction of average rate & Demand charge, \$/peak kW/m \\
\hline \multirow{3}{*}{ Summer } & 1 p.m. -4 p.m. & 1.375 & 10 \\
\cline { 2 - 3 } & 4 p.m. -5 p.m. & 4.375 & \\
\cline { 2 - 3 } & 5 p.m. -7 p.m. & 1.375 & \\
\cline { 2 - 3 } & 7 p.m. -1 p.m. & .7125 & \\
\hline Winter & 1 p.m. -7 p.m. & .9125 & 10 \\
\hline
\end{tabular}


7 p.m. -1 p.m.

.7125

\subsection{Approximate IHP Impact on Photovoltaic (PV) System Costs for a ZEH}

Using the BEopt program developed by NREL (Anderson et al., 2004) analyses for 1800-

$\mathrm{ft}^{2}$, all-electric houses in all five locations were performed. Summary output plots of the sum of incremental mortgage costs plus utility costs from this analysis are presented in figures $8-12$.

Using the energy savings for HVAC/WH computed for the IHP systems and their estimated installed costs from above, energy savings (vs. the Building America Research benchmark house) and mortgage + utility costs for a ZNE house w/IHP were estimated and plotted on Figures 8-12. The procedure used to estimate the IHP mortgage + energy costs is as follows:

- HVAC/WH-related energy consumption \& monthly costs for the ZEH from the BEopt analysis were extracted from the detailed BEopt output;

- HVAC/WH-related energy use and costs were estimated for the ZEH assuming baseline system efficiencies;

- IHP system energy savings were applied to the ZEH with baseline system HVAC/WH-related energy uses;

- IHP system incremental monthly mortgage costs were estimated based on the relationship between monthly mortgage cost and total system cost at the $100 \%$ energy savings point from the BEopt output;

- IHP system monthly utility costs were estimated based on the monthly utility costs at the zero energy savings (BA benchmark) point from the BEopt output; and

- Total mortgage + utilities costs for the ZEH with IHP were estimated.

NOTE - The sum of mortgage and utility costs from BEopt DO NOT include separate dedicated dehumidification equipment. Therefore, results of the analyses in this section are based on space heating, space cooling, water heating, and ventilation equipment and energy costs only. 


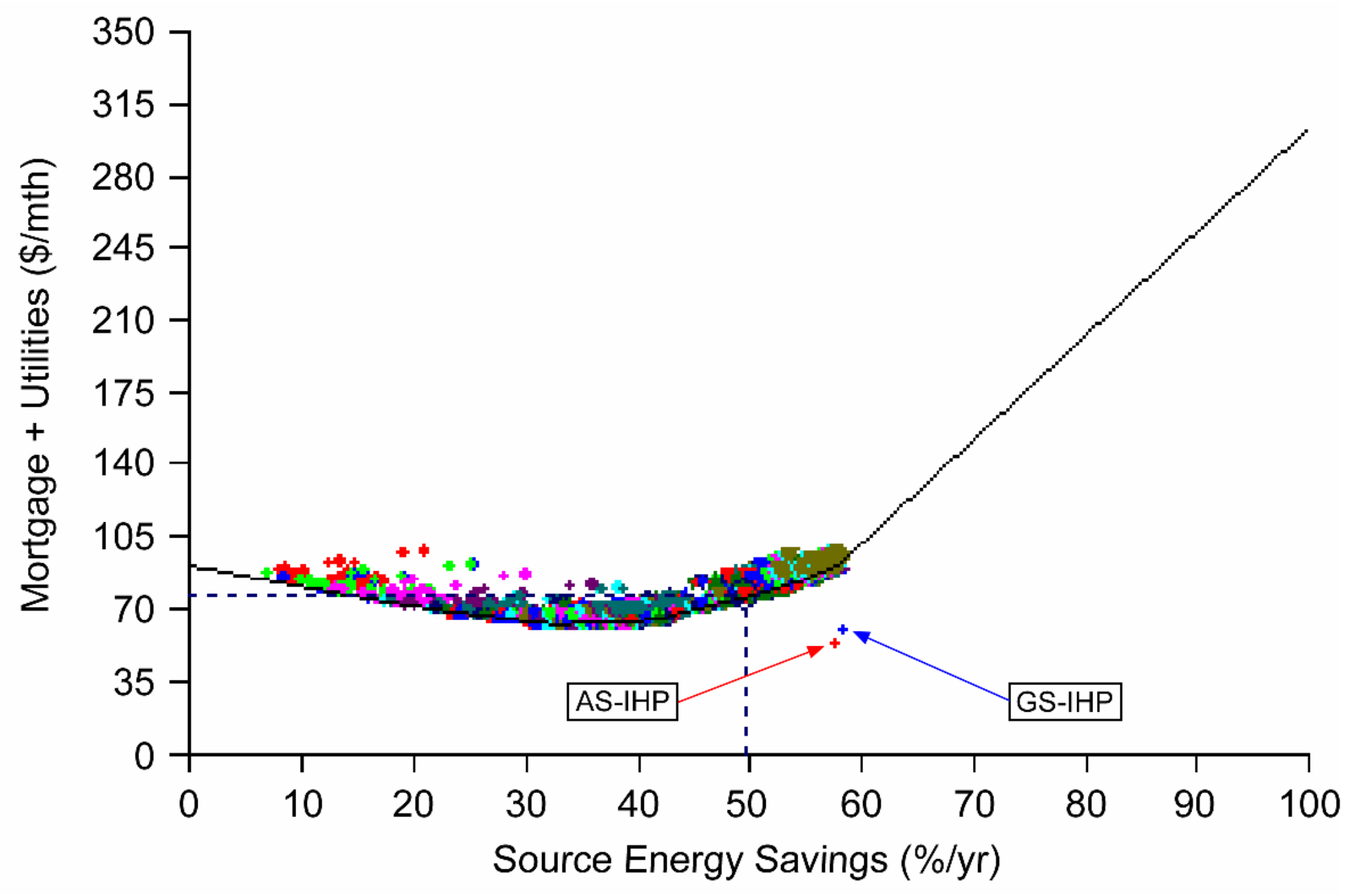

Fig. 8. Incremental mortgage + utilities costs for $1800-\mathrm{ft}^{2} \mathrm{ZEH}$ in Atlanta (from NREL BEopt analysis). 


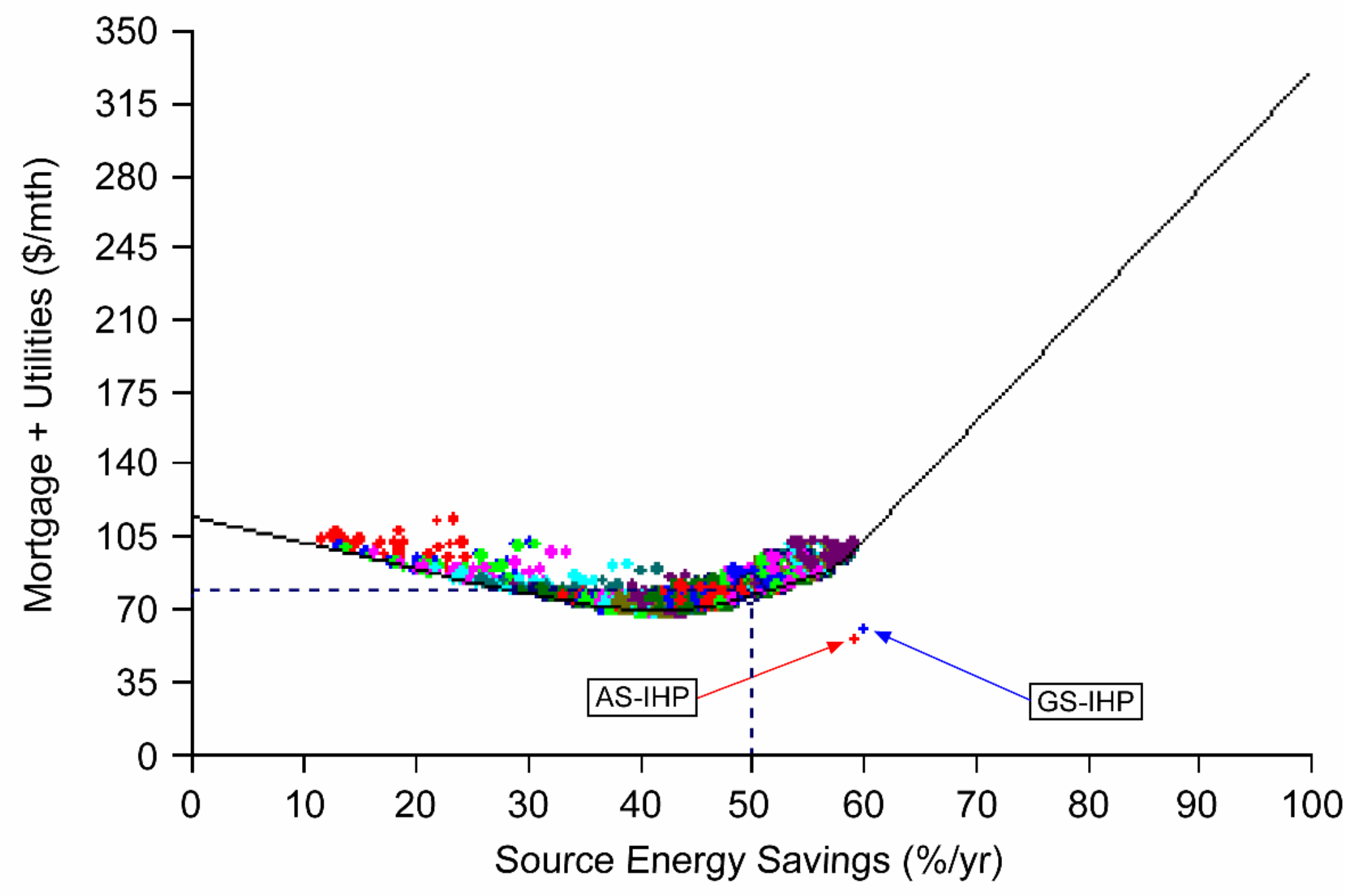

Fig. 9. Incremental mortgage + utilities costs for $1800-\mathrm{ft}^{2} \mathrm{ZEH}$ in Houston (from NREL BEopt analysis). 


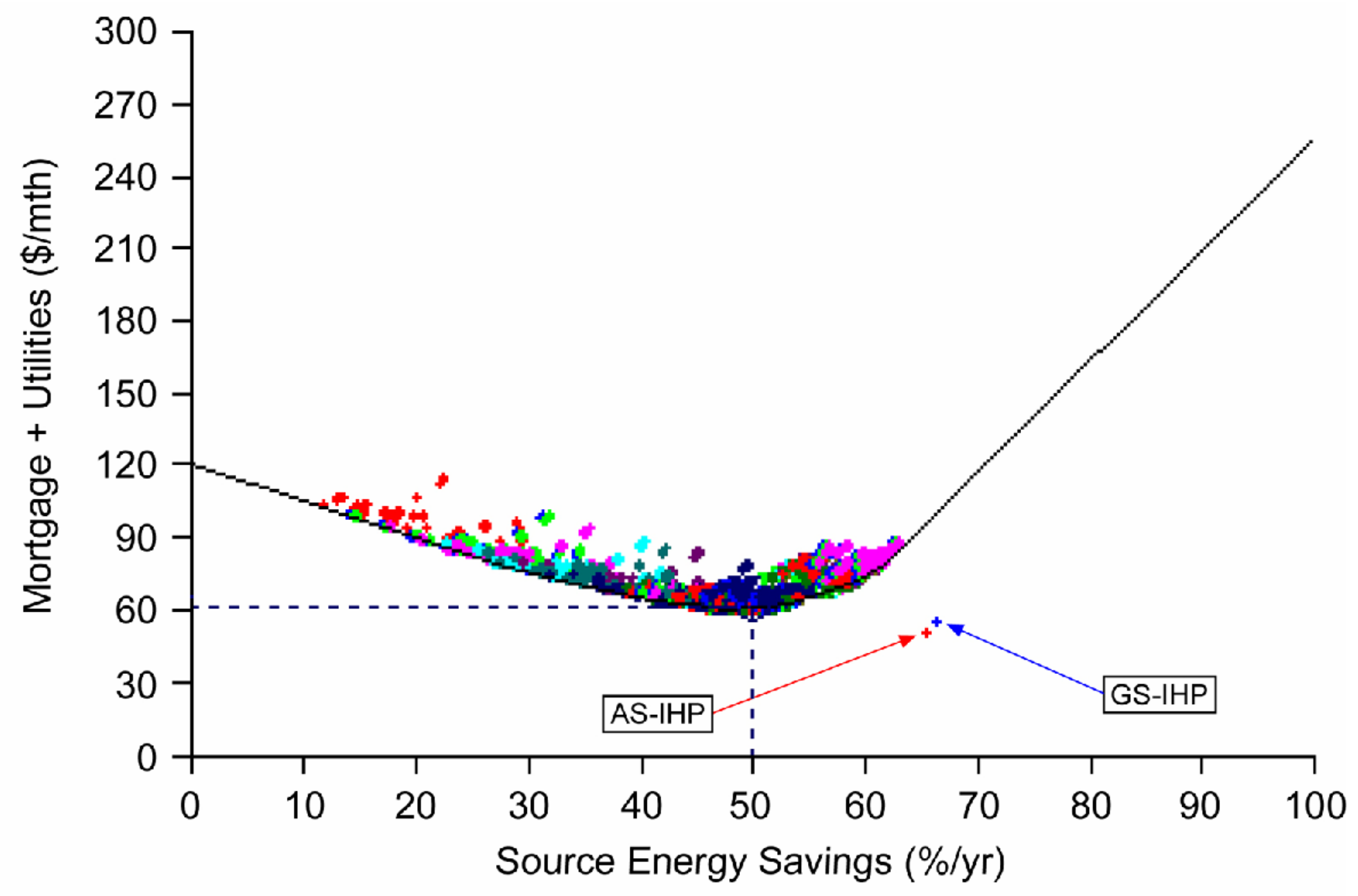

Fig. 10. Incremental mortgage + utilities costs for $1800-\mathrm{ft}^{2}$ ZEH in Phoenix (from NREL BEopt analysis). 


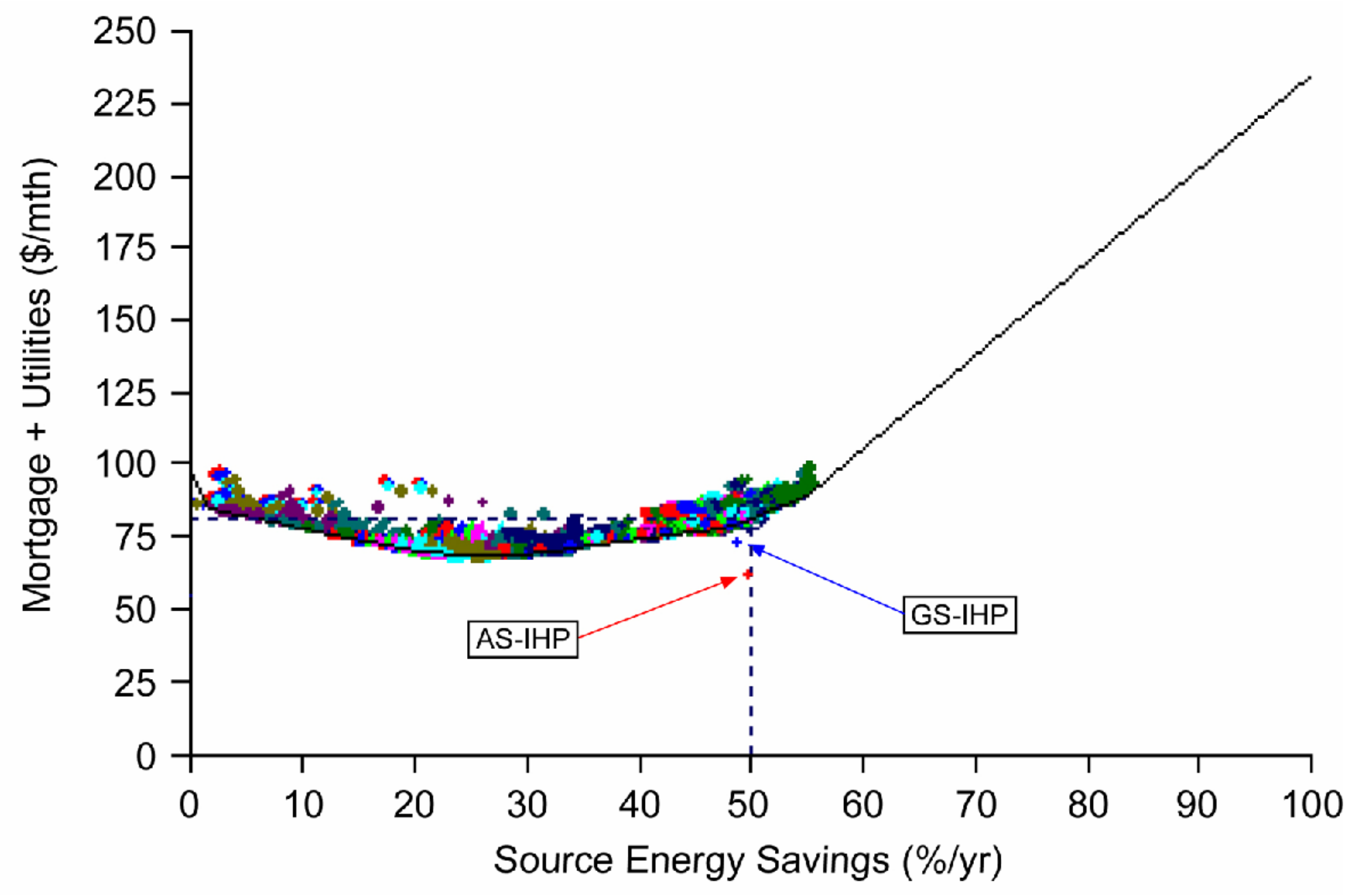

Fig. 11. Incremental mortgage + utilities costs for $1800-\mathrm{ft}^{2} \mathrm{ZEH}$ in San Francisco (from NREL BEopt analysis). 


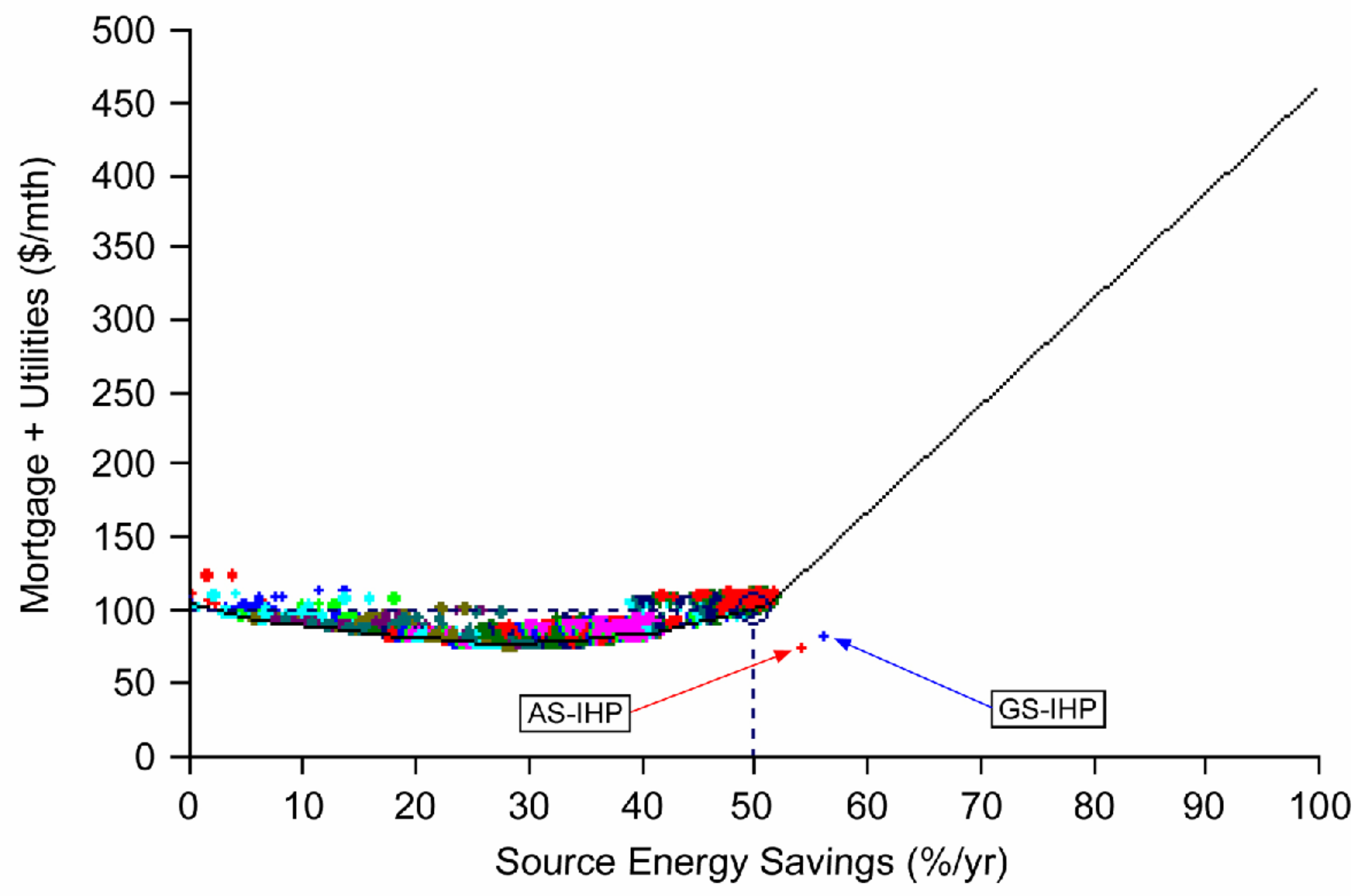

Fig. 12. Incremental mortgage + utilities costs for $1800-\mathrm{ft}^{2} \mathrm{ZEH}$ in Chicago (from NREL BEopt analysis). 
Note that in every location, the estimated IHP mortgage+utility costs are below the least cost curve generated by the BEopt analysis and in many cases to the right as well. Table 16 summarizes the results (note that cost for items related to the dedicated DH operation, $\sim 1 / 2$ of the water piping, the water/air HX, and the tempering water control valve are deducted from the IHP incremental cost for this estimate). The estimated reductions in PV system costs required to reach the ZEH (100\% savings) point range from a low of $\$ 1100$ in San Francisco to a high of $\sim \$ 10,000$ in Chicago. Based on this observation it appears that both IHP systems have potential to significantly reduce the total cost required for a $\mathrm{ZEH}$. In order to more precisely assess the impact of IHP technology on $\mathrm{ZEH}$ system costs, it will need to be fully implemented into the BEopt model environment as an equipment option so it can be evaluated in concert with the other equipment options within BEopt.

Table 16. Estimated PV cost savings from use of AS-IHP or GS-IHP (for space heating and cooling, water heating, and ventilation only) in a ZEH

\begin{tabular}{|l|c|c|c|c|c|c|c|c|}
\hline \multirow{2}{*}{ City } & \multicolumn{2}{|c|}{$\begin{array}{c}\text { IHP incremental } \\
\text { cost }^{1}\end{array}$} & \multicolumn{2}{|c|}{ Est. energy savings } & \multicolumn{2}{c|}{$\begin{array}{c}\text { Est. mortgage }+ \\
\text { utility costs }(\$ / \mathrm{m})\end{array}$} & \multicolumn{2}{c|}{$\begin{array}{c}\text { Estimated PV cost } \\
\text { reduction }\end{array}$} \\
\cline { 2 - 9 } & AS-IHP & GS-IHP & AS-IHP & GS-IHP & AS-IHP & GS-IHP & AS-IHP & GS-IHP \\
\hline Atlanta & $\$ 2,615$ & $\$ 3,415$ & $57 \%$ & $59 \%$ & $\$ 59$ & $\$ 62$ & $\$ 6,000$ & $\$ 6,400$ \\
\hline Houston & $\$ 2,615$ & $\$ 3,415$ & $59 \%$ & $60 \%$ & $\$ 63$ & $\$ 66$ & $\$ 8,300$ & $\$ 8,600$ \\
\hline Phoenix & $\$ 2,653$ & $\$ 3,703$ & $65 \%$ & $66 \%$ & $\$ 53$ & $\$ 57$ & $\$ 8,900$ & $\$ 9,100$ \\
\hline San Francisco & $\$ 2,603$ & $\$ 3,153$ & $49 \%$ & $48 \%$ & $\$ 66$ & $\$ 73$ & $\$ 2,800$ & $\$ 1,100$ \\
\hline Chicago & $\$ 2,615$ & $\$ 3,415$ & $54 \%$ & $56 \%$ & $\$ 82$ & $\$ 84$ & $\$ 9,100$ & $\$ 10,200$ \\
\hline
\end{tabular}

${ }^{1}$ maximum from Tables $10 \& 11$ less cost of dedicated DH items.

2 savings for ZNE house w/IHP relative to BA Benchmark House w/ ca late 90's equipment efficiencies.

\section{SCORING OF OPTIONS VERSUS CRITERIA}

Both options have been scored using the criteria and weighting factors described earlier in this report by the ORNL equipment research team, which is one perspective. Detailed results are given in Appendix A. Each system option received essentially identical scores and based on this result the ORNL team recommends that both be advanced to the next appropriate development steps. It is DOE's prerogative to revisit the criteria and obtain scoring from additional perspectives as part of its decision making process. If the criteria change, the ORNL team will be happy to re-score.

\section{CONCLUSIONS AND RECOMMENDATIONS}

The two top-ranked HVAC/WH systems arising from the FY05 scoping study (Baxter 2005) have been applied to prototype $1800-\mathrm{ft}^{2}$ NZE houses in five cities (Atlanta, Houston, Phoenix, San Francisco, and Chicago) and their energy and peak power savings estimates from the FY05 study refined using detailed hourly analyses. In addition, initial estimates of the installed costs for each system were prepared along with an estimate of PV cost reduction potential. These energy and cost estimates were compared to those of a suite of baseline equipment required to meet all the energy service requirements of a 
ZEH (space heating, space cooling, ventilation, water heating, and demand dehumidification).

The following specific conclusions are highlighted.

1. Both IHP systems achieved (or very nearly achieved) the $50 \%$ energy savings target in all locations except Chicago. In these four cities AS-IHP savings for HVAC/WH/DH energy services ranged from $49.9 \%$ to $52.2 \%$ while the GS-IHP savings ranged from $49.2 \%$ to $55.4 \%$. GS-IHP savings exceeded AS-IHP savings by a 2.3-5.5 percentage point spread except for San Francisco (52.2\% savings for AS vs. $49.2 \%$ for GS). In Chicago, savings were $39.9 \%$ and $44.2 \%$ for the AS and GS systems, respectively. Energy service loads are dominated by SH and WH in Chicago ( $\sim 84 \%$ of total load) and San Francisco ( $\sim 98 \%$ of total load). The control strategy used for the IHPs in the present analyses gave priority to $\mathrm{SH}$ operation during the heating season and one result was that a large portion of the IHP WH energy use was by the electric backup heating elements in all cities but especially so in Chicago and San Francisco.

2. An initial attempt was made to revise the $\mathrm{SH}$ and $\mathrm{WH}$ control logic in winter with encouraging results. When applied to the San Francisco and Chicago cases, backup electric WH energy use dropped considerably and overall energy savings vs. the baseline went up - from 52.2\% and 49.2\% for AS-IHP and GS-IHP, respectively, to $56.3 \%$ and $55.6 \%$ in San Francisco; and from $39.9 \%$ and $44.2 \%$ to $41.8 \%$ and $47.2 \%$ in Chicago.

3. In all locations the IHP showed significant potential to reduce total cost required for a ZEH. Cost reductions ranged from \$2,800 in San Francisco for the AS-IHP to $>\$ 10,000$ in Chicago for the GS-IHP (with winter SH-priority controls)

4. Base scenario (no system cost reduction or utility cost incentives) simple payback of the IHP systems vs. the baseline system in the ZEH were, perhaps predictably, relative high ranging from about 5.5 to 10 years for the AS-IHP and 6 to 11 years for the GS-IHP (with vertical bore ground HX). For a scenario of a $\$ 1000$ system tax credit combined with a favorable time-of-use + demand utility rate structure, these paybacks fall to about 2-4.5 years and 2.5-5 years, respectively.

5. Using the long-term ranking criteria as proposed, and based on scoring by the ORNL team; both systems achieved essentially the same priority ranking. The rankings based on the ORNL team scores represent one perspective. It is DOE's prerogative to revisit the criteria and obtain scoring from additional perspectives as part of its decision making process. If the criteria change, the ORNL team will be happy to re-score.

The following specific recommendations are made.

1. Based on the conclusions above, the ORNL team recommends that both the ASIHP and GS-IHP be advanced to the next appropriate development steps.

2. Additional IHP controls development is suggested to optimize IHP WH mode efficiency without compromising indoor temperature control. 
3. Evaluation of an economizer operation mode, or "free cooling" mode, is recommended to determine possible energy savings impacts in the various locations.

4. Evaluation of the including the additional energy service of winter humidification to prevent excessively "dry" indoor conditions is recommended.

\section{REFERENCES}

ACCA (1995). Residential Duct Systems - Manual D. Air Conditioning Contractors of America, Washington, DC.

ACH\&R News (2006). "How High Will SEER Go? 23 Now, But Future Likely Holds More." Volume 228, Number 15, August 7, 2006.

Ally, M. R. (2006a). Data and Analyses of SWS performance in Field Experiments for Interim DOE Go/No-Go Decision: Oak Ridge National Laboratory, June 30 DRAFT.

Ally, M. R. (2006b). Personal communication to Van Baxter, July 6.

Anderson, R.; C. Christensen, G. Barker, S. Horowitz, A. Courtney, T. Givler, K. Tupper, (2004). Analysis of System Strategies Targeting Near-Term Building America EnergyPerformance Goals for New Single-Family Homes: FY 2004 Fourth-Quarter Building America Milestone Report. 55 pp.; NREL/TP-550-36920.

ASHRAE (2004a). ANSI/ASHRAE Standard 55-2004: Thermal Environmental Conditions for Human Occupancy.

ASHRAE (2004). ANSI/ASHRAE Standard 62.2-2004: Ventilation and Acceptable Indoor Air Quality in Low-Rise Residential Buildings.

Baxter, V. (2005). HVAC Equipment Design Options for Near-Zero-Energy Homes - A Stage 2 Scoping Assessment. ORNL/TM-2005/194. November.

Brown, R. (2006). Personal communication to Van Baxter, July 12.

Christensen, C. (2005). NREL, e-mail communication with C.K. Rice of ORNL, July 2005.

Christian, J. E. (2006). Personal communication to Van Baxter, July 6.

U.S. Department of Energy, Building Technologies Program (DOE/BT) (2000).

Technical Support Document: Energy Efficiency Standards for Consumer Products:

Residential Water Heaters, December.

DOE/BT (2002). Technical Support Document: Energy Efficiency Standards for Consumer Products: Residential Central Air Conditioners and Heat Pumps, May.

DOE/BT (2005). Building Technologies Program Research, Development, Regulatory, and Market Introduction Plan - Planned Program Activities for 2006-2011. Revised Second Generation Draft, August 1. 
DOE/BT (2006). Rulemaking Framework for Commercial Clothes Washers and Residential Dishwashers, Dehumidifiers, and Cooking Products. March 15. (www.eere.energy.gov/buildings/appliance standards/residential/dehumidifiers.html)

Ellis, D. (2006). Personal communication to Van D. Baxter, April.

Goldman, C., R. Scheer, W. Kempton (1995). Information and Telecommunication Technologies: The Next Generation of Utility Residential DSM and Beyond.

Presentation at DOE Office of Utility Technologies Program Review, "The Restructuring of the Electric Utility Industry," December 6.

Hendron, R. (2005). Building America Research Benchmark Definition, Updated Dec. 29, 2004. 37 pp.; NREL/TP-550-37529.

Hendron, R., et al. (2004). Building America Performance Analysis Procedures, Revision 1, NREL/TP-550-35567.

Hutchins, J. W. (2006). Personal communication to C. Keith Rice, September 13.

Hoyt, J. B. (2005). Letter to Andrew Fanara and Mehernaz Polad at EPA. April 5. On line at http://www.energystar.gov/index.cfm?c=revisions.dehumid spec.

ICC (2006). 2006 International Energy Conservation Code. Published by International Code Council, Country Club Hills, IL.

Means (2005). Mechanical Cost Data, $28^{\text {th }}$ Annual Edition. RSMeans Construction Publishers \& Consultants.

Murphy, R. W., C. K. Rice, and V. D. Baxter (2006). Integrated Heat Pump (IHP) System Development; Air-Source IHP Control Strategy, and Specifications and GroundSource IHP Conceptual Design — FY06 Milestone Report. ORNL/TM-2006/143, October.

Rudd, A. F., J. W. Lstiburek, P. Eng, K. Ueno (2005). Residential Dehumidification Systems Research for Hot Humid Climates. NREL/SR-550-36643, February.

Solar Energy Laboratory (Univ of WI), TRANSSOLAR Energietechnik, CSTB - Centre Scientifique et Technique du Bâtiment, and TESS - Thermal Energy System Specialists, 2006. TRNSYS 16: a TRaNsient SYstem Simulation program, Version 16.01.0000.

Southern California Edison (2005). DEER Residential SEER-Rated Units Performance Maps - Phase 2 Report: Performance Maps and Methodology Development. February.

Schoen, P. (2006). Personal communication to Van D. Baxter, May.

Thorne, J. (1998). Integrated Space Conditioning and Water Heating Systems: One System is Often Better than Two. American Council for an Energy-Efficient Economy. Report Number A982. December.

Tomlinson, J. J., C. K. Rice, R. W. Murphy, and Z. Gao (2005). Assessment and Initial Development of a Small, High-Efficiency Heat Pump System for NZEH - FY05 Milestone Report, September 29. 
Witte, M. J. and R. H. Henninger (2006). ASHRAE 1254-RP, Evaluating the Ability of Unitary Equipment to Maintain Adequate Space Humidity Levels, Phase II - Final

Report-Appendices. American Society of Heating, Refrigerating, and Air-Conditioning Engineers, Atlanta, GA, May 31. 


\section{APPENDIX A}

The scoring of options versus the criteria is summarized in Table A1. The composite team score is shown in the "criteria" column, the criteria weighting factor is in the "weight" column, and the "score" is the product of the previous two columns.

Table A1. HVAC longer-term option assessment scores

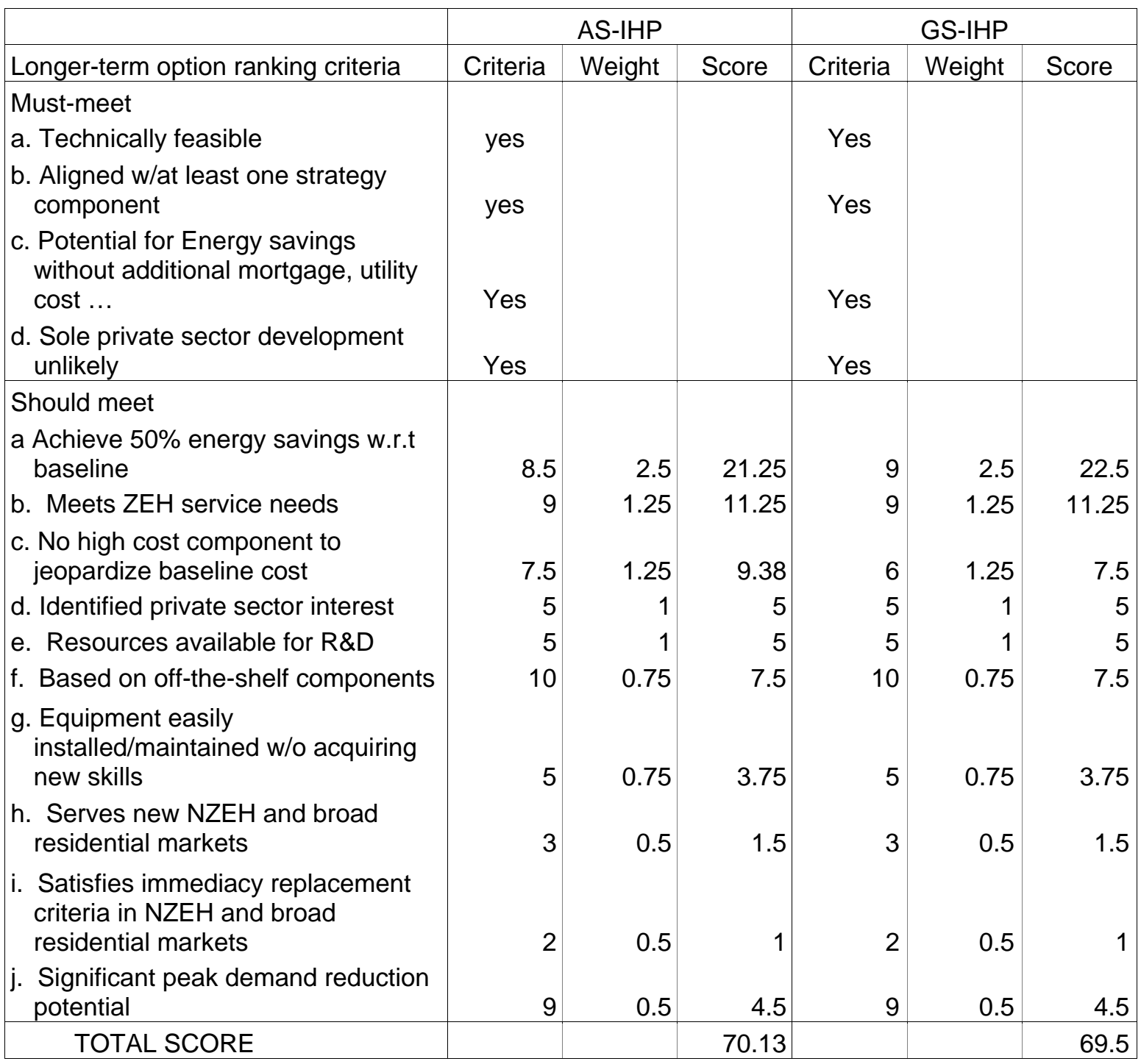

